\title{
Public Disclosure of Private Meetings: Does Transparency of Corporate Site Visits affect Analysts' Attention Allocation?*
}

\author{
Yi Ru \\ Renmin University of China \\ ruyi@rmbs.ruc.edu.cn \\ Ronghuo Zheng \\ The University of Texas at Austin \\ Ronghuo.Zheng@mccombs.utexas.edu \\ Yuan Zou \\ Harvard Business School \\ yzou@hbs.edu
}

October 2020

\begin{abstract}
We investigate the consequences of increased transparency of corporate site visits on financial analysts' attention allocation. Using the timely disclosure requirement by the Shenzhen Stock Exchange (SZSE) in China since July 2012 as a setting, we find that non-visiting analysts reduce attention allocated to visited firms relative to non-visited firms. These results are consistent with the conjecture that such transparency reveals the information advantage of visiting analysts relative to non-visiting analysts, who then reallocate attention across different firms. Cross-sectional analyses suggest that the effects are more pronounced when the information advantage is larger. Further evidence suggests that such transparency has positive spillover effects on peer firms' informational efficiency by influencing analysts' attention allocation. Thus, despite the potential disclosure costs directly imposed on firms, firms collectively can benefit from this disclosure requirement due to the positive spillover effects.
\end{abstract}

Keywords: attention allocation, analysts, timely disclosure, corporate site visits

JEL Codes: G24, G14, M41

\footnotetext{
* We thank John Barrios, Wei Cai, Dennis Campbell, Ed deHaan, Fabrizio Ferri, Jonathan Glover, Paul Healy, Bob Kaplan, Zhiming Ma, Krishna Palepu, Eugene Soltes, Suraj Srinivasan, Charles Wang, David (Xiaoyu) Xu, Ben Yost, Frank Yu, Yong Yu, Ran Zhang, Wuyang Zhao, and seminar participants at Harvard Business School, Peking University, Renmin University, and Early Insights of Accounting Research Webinar for their constructive comments. We also thank Datago Technology Ltd. for providing data on corporate site visits before 2012 and Hao Luo from Barclays for providing useful institutional insights. Zhuoran Dai and Ronger Wen provided excellent research assistance.
} 
If you know the enemy and know yourself, you need not fear the result of a hundred battles. If you know yourself but not the enemy, for every victory gained you will also suffer a defeat.

- Sun Tzu, The Art of War

\section{Introduction}

Information acquisition has laid the foundation of financial markets (e.g., Grossman and Stiglitz, 1980). Economic agents like financial analysts have limited time, energy, and resources, which constrain their capacity to acquire information (Kahneman, 1973; Sims, 2003). Given their limited information acquisition capacity, how financial analysts collectively allocate their attention across firms has important implications for the capital market as a whole (Blankespoor et al., 2020).

In this paper, we investigate how the timely information of peer analysts' information acquisition activities affects analysts' attention allocation. Specifically, using the timely disclosure requirement for Chinese companies in 2012 as the empirical setting, we examine whether and how the increased transparency of private meetings affects financial analysts' attention allocation across firms. Private meetings such as corporate site visits are an important way for analysts to acquire information (Soltes, 2014; Brown et al., 2015; Solomon and Soltes, 2015). However, peer non-visiting analysts typically do not directly observe when and with whom the meetings occur (Soltes, 2014; Solomon and Soltes, 2015). The timely availability of such information would allow these analysts to be aware and take actions.

As important information intermediaries, analysts process information and facilitate communication between firms and investors (Healy and Palepu, 2001). Evidence suggests that competition plays an important role in shaping analysts' behavior (e.g., Hong and Kacperczyk, 2010; Merkley et al., 2017), and analysts tend to provide new information to distinguish 
themselves from their peers (Crawford et al., 2012). Prior studies document that analysts who visit a firm and privately meet with managers gain an information advantage and issue more accurate forecasts (Cheng et al., 2016; Han et al., 2018). When a firm discloses analysts' recent visits in a timely manner, investors and non-visiting analysts realize those with the information advantage for this visited firm. Hence, investors interested in the visited firm may more likely demand information from visiting analysts than from non-visiting analysts. Non-visiting analysts would likely experience a reduction in both information demand from investors and new information that is available to learn through additional visits. ${ }^{1}$ Therefore, non-visiting analysts are likely to pay less attention to the visited firm. ${ }^{2}$

While it is plausible that non-visiting analysts might allocate relatively less attention to acquire information about the visited firm, it is not obvious. Corporate site visits often occur when there is value-relevant information that is not yet well known or understood by the public (Cheng et al., 2019). ${ }^{3}$ Timely disclosure of corporate site visits might reveal the existence of value-relevant information. Despite that visiting analysts might have gathered some insights about the visited firm, the mosaic theory suggests that other analysts may still discover new information by conducting additional visits because they can form different information "mosaic" using their

\footnotetext{
${ }^{1}$ This statement is of course true if the visit reveals that there is no new information. Otherwise, the information acquired by visiting analysts will eventually be revealed as brokerage houses provide analysts with incentives to satisfy clients' information demand (Brown et al., 2015). In addition, Li, Wong, and Yu (2020) suggest that in China, analysts can disseminate information either via public earnings forecasts or privately to other analysts with whom they share close ties.

${ }^{2}$ The theory and evidence in Van Nieuwerburgh and Veldkamp (2009) also suggest that market participants such as investors benefit more from knowing what others do not know.

${ }^{3}$ Van Nieuwerburgh and Veldkamp (2010) build a framework with an investor with limited attention and show that the investor is more likely to pay attention to and learn about stocks they are uncertain about. Intuitively, the investor would like to set the posterior uncertainty about all stocks equal and thus learn comparatively more about stocks that have higher prior uncertainty.
} 
expertise or private information (Solomon and Soltes, 2015). ${ }^{4}$ Hence, non-visiting analysts may in fact allocate more attention to the visited firm. ${ }^{5}$ Given this counter argument, it is an open question as to how the increased transparency of corporate site visits affects financial analysts' attention allocation to acquire information for different firms.

To address this question, we use the timely disclosure requirement of corporate site visits by the Shenzhen Stock Exchange (SZSE) in China in July 2012 as the empirical setting. Beginning in 2009, the SZSE-listed firms were effectively required to disclose information about corporate site visits in their regular periodic reports (i.e., annual, semi-annual, and quarterly). ${ }^{6}$ Specifically, firms were required to disclose the identities of participants, meeting dates, locations, and descriptions of meeting topics. Beginning in July 2012, these firms were required to disclose such information within two trading days following a corporate site visit. In other words, the 2012 regulation requires firms to disclose the information about corporate site visits in a much timelier fashion. We exploit this setting to examine how the timely disclosure affects financial analysts' attention allocation across firms. ${ }^{7}$

We first compare changes in analysts' attention allocated to firms that hosted site visits from 2009-2011 to 2013-2015, relative to concurrent firms that did not host site visits (non-visited firms). We find that following the 2012 timely disclosure requirement, when a firm hosts corporate

\footnotetext{
${ }^{4}$ Value-relevant information does not need to be material information itself. In fact, disclosing material information during private meetings is against the framework of Reg FD. However, visiting analysts can become informed by assessing non-material information and forming an information "mosaic" using their expertise or information endowment.

${ }^{5}$ Firms may also use the disclosed site visits to attract market attention, despite that visiting analysts might have requested not to publicly disclose their visits without the disclosure requirement.

${ }^{6}$ Regular periodic reports include annual, semi-annual, and quarterly reports.

${ }^{7}$ Prior to 2012, most firms only disclose the names of the visiting brokers; after 2012, firms are required to disclose the names of the visiting analysts. Because a broker usually has only one analyst covering a specific firm, we use "broker" and "analyst" interchangeably.
} 
site visits during a week, non-visiting analysts subsequently reduce their tendency to visit the same firm compared to other non-visited firms. These results are consistent with the conjecture that timely disclosure reveals visiting analysts' information advantage so non-visiting analysts would likely allocate less attention to the visited firm relative to other firms. Our results are robust to using the tendency to issue forecast revisions as another proxy for analysts' attention. We also find that prior to 2012, there are no differential trends in analysts' attention allocated to visited firms compared to non-visited firms, supporting the parallel trend assumption. A set of cross-sectional tests indicate the results to be stronger when the potential information advantage of visiting analysts is larger (e.g., when the disclosed corporate site visits involved star analysts or analysts that have recently visited or issued earnings forecasts for the firm). Besides analysts, as another important group of market participants, mutual funds also visit firms. We therefore also examine whether the same result can be applied to mutual funds and find our main result holds when we include mutual funds (along with analysts) as visiting entities or focus on mutual funds exclusively.

We further predict that the timely disclosure requirement results in non-visiting analysts switching attention from visited firms to non-visited peer firms within the same industry as prior studies suggest that analysts specialize by industry (e.g., Dunn and Nathan, 2005; Bradshaw, 2011). We indeed find that when a greater proportion of a non-visited firm's industry peers host site visits, this firm is more likely to be visited during subsequent weeks by non-visiting analysts. The results suggest that analysts increase their attention allocated to non-visited industry peer firms following the implementation of the timely disclosure requirement. ${ }^{8}$

\footnotetext{
${ }^{8}$ It is also possible that the disclosure of a visit reveals the existence of industry-level value-relevant information, which may induce analysts to increase their attention to the non-visited peer firms in the same industry. However, untabulated results suggest that the main results do not vary with the extent to which a visit reflects the existence of industry-level information, suggesting that our main results are not fully driven by this alternative explanation.
} 
We then examine whether the change in analyst attention is associated with consequences in informational efficiency. We document that following the timely disclosure requirement, a visited firm's stock prices reflect slightly greater firm-specific information, as reflected in a reduction in stock return synchronicity (Durnev et al., 2003; Piotroski and Roulstone, 2004; Israeli et al., 2017). More importantly, a non-visited firm's stock prices reflect greater firm-specific information when a greater proportion of its industry peers host visits. These results suggest that the timely disclosure of corporate site visits has positive spillover effects on peer firms' information environment by influencing analysts' attention allocation.

While we focus on analysts' reaction because analysts or investors initiate most site visits (Cheng et al., 2016), the documented pattern may also be attributed to firms' responses as visited firms may negotiate the visiting dates with visitors. For example, the timely disclosure requirement might increase firms' compliance costs so firms may combine several visiting requests into one visit and report once instead of several times after each visit. Ex post, when more analysts visit the firm during a week, it is more likely that the visited firm has combined visiting requests. Ex ante, it is the board secretary who is in charge of public disclosure compliances in China, so a busy board secretary is more likely to combine visiting requests. However, we do not find that visits with multiple analysts or firms with busy board secretaries drive our main results, suggesting that our results are not fully driven by the alternative explanation. ${ }^{9}$ Notwithstanding these results, we acknowledge that firms may still influence the visiting dates.

Our results primarily rely on firms' timely disclosure of the meeting time and identities of the visiting analysts. It is worth noting that meeting topics are also required to be disclosed in a timelier manner, which might provide timely value-relevant information and hence crowd out

\footnotetext{
${ }^{9}$ Since the board secretary is also in charge of organizing board meetings, we use the number of board meetings as a proxy for the busyness of a board secretary's schedule.
} 
further visits by non-visiting analysts. This alternative explanation may not be a big concern as it remains controversial though whether or not the disclosure of meeting topics is informative enough (Bowen et al., 2019). ${ }^{10}$ Untabulated results suggest that there is no change in the extent to which site visits predict future firm performance following the timely disclosure requirement. Despite these arguments, we acknowledge that it is a caveat to the extent that the timely disclosure of meeting topics might affect analysts' information acquisition activities.

Our paper contributes to the literature on the attention allocation of financial analysts. "Rational inattention" models rely on the assumption that economic agents have limited information processing capacity, so they must decide how to allocate their attention across different firms (e.g., Sims, 2003; Sims, 2010; Veldkamp, 2011). ${ }^{11}$ Driskill et al. (2020) find that analysts are less timely and thorough when firms within their coverage portfolios have contemporaneous earnings announcements. Harford et al. (2018) find that analysts strategically allocate more effort to portfolio firms that are relatively more important to their careers. Rather than focusing on firm characteristics, we identify a new factor that affects analysts' attention allocation - the information about peer analysts' information acquisition activities, since analysts are concerned about competition with other analysts. By documenting this new factor, our paper provides insights on the strategic interactions among analysts. Prior studies show analysts' herding behavior (e.g., Clement and Tse, 2005; Jegadeesh and Kim, 2010) and the impact of competition on analysts' earnings forecasts and stock recommendations (e.g., Hong and Kacperczyk, 2010;

\footnotetext{
${ }^{10}$ Furthermore, visiting analysts can learn subtle soft information but such information is often difficult to be precisely disclosed publicly. In contrast, the disclosure of when and with whom the meetings occur, on which our arguments rely, is relatively easy to enforce as such information is often verifiable.

${ }^{11}$ In addition to "rational inattention," limited attention can also arise from behavioral reasons (e.g., DellaVigna and Pollet, 2009; Hirshleifer et al., 2011). For example, Hirshleifer et al. (2019) find that over the course of a day, as the number of forecasts an analyst has already issued increases, the analyst is more likely to resort to more heuristic decisions. Our arguments are based on the limited information processing capacity of analysts, which is more under the rational inattention framework (see Blankespoor et al. (2020) for a review of the rational inattention models).
} 
Merkley et al., 2017). Within the literature on the strategic interactions among analysts, our paper is most closely related to Crawford et al. (2012), who study analysts' coverage initiation that can be seen as analysts' long-term attention allocation. Crawford et al. (2012) show that the first analyst to initiate coverage provides low-cost market and industry information, while subsequent analysts initializing coverage for the same firm typically focus on firm-specific information to distinguish themselves. While our argument also relies on the first-mover advantage of visiting analysts, our results suggest that non-visiting analysts might respond by shifting their attention from the visited firm to peer non-visited firms in the short term.

Our paper also contributes to the literature on the spillover effects of firms' public disclosure. Leuz and Wysocki (2016) call for more studies on the externalities of reporting standards and disclosure regulations. Shroff et al. (2017) provide evidence suggesting that the peer information environment is negatively associated with a firm's cost of capital. Breuer et al. (2018) document that regulated firms' mandatory disclosures crowd out unregulated firms' voluntary disclosures. De George et al. (2019) find that firms lose investors' attention when their peers choose to report quarterly instead of semi-annually and such loss of attention is associated with a decrease in market value and market liquidity. In contrast, we find that public disclosure of private meetings can have positive spillover effects on peer firms' informational efficiency because nonvisiting analysts are likely to shift their attention to these peer firms. In this respect, although our study utilizes a unique setting in China, we shall not restrict our findings to the Chinese capital market. We contribute to the policy debate regarding the mandated disclosure of private meetings in the United States since it has been suggested the U.S. Securities and Exchange Commission (SEC) should increase such transparency (e.g., Bengtzen, 2016). Despite the potential disclosure 
costs directly imposed on firms, firms collectively can benefit from this disclosure requirement due to the positive spillover effects through the influence on analysts' attention allocation.

The rest of the study proceeds as follows. Section 2 provides institutional background, research design, and the description of the sample. Section 3 reports the main results, followed by the effects on firms' informational efficiency in Section 4. Section 5 discusses additional analyses, and Section 6 concludes.

\section{Institutional Background, Research Design, and Sample Description}

\subsection{Institutional Background}

Aiming to prevent public companies from selectively disclosing important news to certain investors, in August 2006 the SZSE in China proposed Information Fair Disclosure Guidelines, which is similar to the 2000 U.S. Regulation Fair Disclosure (Reg FD) rules. The 2006 guidelines also recommend public companies to record and publicly disclose the identities of private-meeting participants in regular periodic reports (e.g., in annual, semi-annual, and quarterly reports). The SZSE revised the guidelines on July $2^{\text {nd }}, 2007$ and required public companies listed on the mainboard to record private meetings in a recommended format beginning with the 2007 semiannual reporting period. ${ }^{12}$ It began to be strictly enforced in 2009 when almost all public firms listed on the mainboard of SZSE began reporting private meetings in their regular periodic reports. ${ }^{13}$ During the same period, some firms listed on the Small and Medium-sized Enterprises

\footnotetext{
${ }^{12}$ See the Guidelines on Improving 2007 Semi-annual Reporting issued by SZSE on July ${ }^{\text {nd }}$, 2007. This mandatory public disclosure requirement did not apply to firms listed on the Small and Medium-sized Enterprises (SME) Board and the Growth Enterprises Market (GEM) Board. Prior to the 2012 timely disclosure requirement, firms listed on the SME Board and the GEM Board had been required to report the corporate site visits to SZSE within two trading days and five trading days (but not publicly), respectively.

${ }^{13}$ Technically, the Information Fair Disclosure Guidelines was issued in 2006 but during 2007-2008 in our database we did not observe many firms that actually disclosed corporate visits in their annual reports, which indicates that
} 
(SME) Board and the Growth Enterprises Market (GEM) Board also voluntarily disclosed the private meeting events. The records are brief and typically included meeting dates, locations, outside participants' affiliations (sometimes their names) and a short summary of meeting topics. More importantly, the information provided in these periodic reports is not timely.

In July 2012, the disclosure requirement began to be more strictly enforced because the SZSE then required all A-list public firms (including all public firms listed on the Main, SME, and GEM boards) to record and disclose investor relation activities in a standard format within two days on the SZSE online investor service platform: HudongYi (hereafter referred to as the timely disclosure requirement). ${ }^{14}$ This standard format includes the names of participating institutions and individuals, meeting dates and locations, the names of hosting personnel, and descriptions of meeting topics. ${ }^{15}$ Appendix 1 provides an example of site visit records, showing that after 2012, the company provides timelier disclosure about corporate site visits. Notably, the disclosure of participants in private meetings becomes much more detailed after the 2012 timely disclosure requirement. For example, before 2012, most firms only disclosed the names of institutions or affiliated brokerages in regular periodic reports but not the names of analysts, while after July 2012, the identities of analysts are typically disclosed by most firms. The timely disclosure requirement applies to all investor relation activities, including corporate site visits, conference calls, performance announcement meetings, media interviews, etc. We focus on corporate site

\footnotetext{
there might have been some delay until the guidance was strictly and effectively enforced in 2009 . Hence, we use 2009 as the first year of our pre-period as that was when the guidance had been effectively enforced, which we believe could help us better identify the effects of the timely disclosure requirement.

${ }^{14}$ The official website of the SZSE's Hudong Yi platform is http://irm.cninfo.com.cn/szse/.

${ }^{15}$ There are still some firms that sometimes did not publicly disclose their private meeting events within two days after July 2012. It does not compromise the fact that overall this information is much timelier after July 2012 compared to being disclosed in regular periodic reports.
} 
visits exclusively because analysts often initiate site visits that require significant time and resources (Cheng et al., 2018; So et al., 2020). ${ }^{16}$

Besides SZSE, the Shanghai Stock Exchanges (SHSE) is another important stock market exchange in China. A similar online investor service platform SHSE-eHudong was introduced by SHSE in July 2013 to implement a similar version of timely disclosure requirement. Nonetheless, SHSE had no previous requirement for public firms to disclose private meetings in their regular periodic reports by SHSE. Without data for corporate site visits before the SHSE's 2013 timely disclosure requirement, we are unable to differentiate visiting and non-visiting analysts and thus adopt a similar design to study how the timely disclosure requirement changed non-visiting analysts' subsequent reactions. ${ }^{17}$ Hence, we only use the SZSE's 2012 timely disclosure requirement as our study setting.

\subsection{Research Design}

Our identification strategy exploits the nature of the SZSE's timely disclosure requirement that triggers timely public disclosure when there is a corporate site visit after 2012. Specifically, we examine the change in analysts' attention allocated to a visited firm relative to non-visited firms after the requirement is implemented (as only visited firms are treated by the timely disclosure requirement). In other words, in 2009-2011 (pre-period), visited firms disclose the private meetings in periodic reports while non-visited firms disclose nothing. In 2013-2015 (post-period), visited firms disclose the private meetings within two business days after each visit while nonvisited firms still disclose nothing.

\footnotetext{
${ }^{16}$ While corporate site visits provide a stronger setting to examine our research question, our results are qualitatively similar if we include other investor relation activities.

${ }^{17}$ One legitimate concern is that before 2012 visiting analysts might have disclosed in their reports that their earnings forecasts and recommendations are based on the recent site visits. However, according to Cheng et al. (2016), only $11.97 \%$ of forecast revisions are issued by visiting analysts in the month after their site visits.
} 
We focus on firm-week-level analyses to capture the short-term responses to the timely disclosure of site visits. ${ }^{18}$ The firm-week-level analyses also help avoid misclassifying visiting analysts as non-visiting analysts because some site visits fall on adjacent dates (Cheng et al., 2016). In particular, for each week $t$, we define visited (and non-visited) firms as those with (and without) site visits. We adopt the following difference-in-differences (DiD) design using data in 2009-2011 and 2013-2015:

$$
\begin{aligned}
\text { Attention }_{i, t}= & \alpha+\beta_{1} \text { Dvisit }_{i, t}+\beta_{2} \text { Post }_{i, t}+\beta_{3} \text { Dvisit }_{i, t} \times \text { Post }_{i, t} \\
& +\beta_{4} \text { Other Controls }+\varepsilon_{i, t} .
\end{aligned}
$$

$D v i s i t_{i, t}$ is an indicator variable which equals one if firm $i$ has at least one visit in week $t$, and zero otherwise. Post $t_{i, t}$ is an indicator variable which equals one if week $t$ is in year 2013-2015, and zero if week $t$ is in year 2009-2011. ${ }^{19}$ Attention ${ }_{i, t}$ captures the attention allocated by analysts to firm $i$ subsequent to week $t$. To capture the subsequent attention, we examine whether analysts tend to visit firm $i$ during subsequent weeks. For a visited firm in week $t$, we measure Attention ${ }_{i, t}$ as an indicator variable which equals one if at least one non-visiting analyst (i.e., an analyst who does not visit the firm in week $t$ ) visits the firm during subsequent weeks. For a non-visited firm $i$, since none of the analysts visit firm $i$ in week $t$, we measure Attention $_{i, t}$ as an indicator variable which equals one if at least one analyst visits the firm during subsequent weeks. We use $D v i s i t F 1_{i, t}$ $\left(D v i s i t F 2_{i, t}, D v i s i t F 3_{i, t}, D v i s i t F 4_{i, t}\right)$ to indicate the attention paid to firm $i$ in the subsequent week

\footnotetext{
${ }^{18}$ A longer window such as a month or a quarter might capture effects of other events besides the timely disclosure of site visits while a shorter window than a week may not be long enough to allow non-visiting analysts to respond and adjust their visiting schedule.

${ }^{19}$ In principle, a logistic or probit model is more appropriate for discrete dependent variables. However, such a model may not adequately control for the fixed effects on the dependent variable as the regression may not converge, and the fixed-effect variables may suffer from severe information loss (e.g., some firms may not have private meetings at all during the entire sample period). Thus, we turn to the linear probability model (LPM) for estimation.
} 
(two weeks, three weeks, four weeks). ${ }^{20}$ The window ranges from one to four weeks in case some firms delay the disclosure or the non-visiting analysts might not timely respond to the disclosure. We do not use windows beyond four weeks as a longer window might capture factors affecting analysts' visiting decisions other than the disclosures themselves. Our main variable of interest, Dvisit $_{i . t} \times$ Post $_{i, t}$ captures how non-visiting analysts change their attention allocated to visited firms relative to non-visited firms from the pre-period (when visited firms are not required to make timely disclosures in 2009-2011) to the post-period (when visited firms are required to make timely disclosures in 2013-2015).

To examine the next question whether analysts increase attention allocated to non-visited firms within the same industry, we estimate the following regression equation using the sample of non-visited firm-weeks:

$$
\begin{aligned}
\text { Attention_nonvisit }_{i, t}= & \alpha+\beta_{1} \text { Peervisit }_{i, t}+\beta_{2} \text { Post }_{i, t}+\beta_{3} \text { Peervisit }_{i, t} \times \text { Post }_{i, t} \\
& +\beta_{4} \text { Other Controls }+\varepsilon_{i, t} .
\end{aligned}
$$

Peervisit $t_{. t}$ captures the proportion of peer firms within firm $i$ 's industry that are visited during week $t$. Post $t_{i, t}$ is an indicator variable which equals one if week $t$ is in year 2013-2015, and zero if week $t$ is in year 2009-2011. Attention_nonvisit ${ }_{i, t}$ captures the subsequent attention allocated to a non-visited firm $i$ by analysts who do not visit any peer firms in week $t$. To capture the subsequent attention allocated by these analysts, we examine whether these analysts tend to visit firm $i$ during subsequent weeks. Specifically, DvisitF $1_{i, t}\left(\right.$ DvisitF $\left._{i, t}, D v i s i t F 3_{i, t}, D v i s i t F 4_{i, t}\right)$ is an indicator variable which equals one if at least one of the non-visiting analysts (i.e., analysts who do not visit any peer firms in week $t$ ) visit firm $i$ in the subsequent week (two weeks, three weeks, four weeks),

\footnotetext{
${ }^{20}$ All the tests in this paper examine the dependent variables in four different windows (i.e., next week, next two weeks, three weeks, and four weeks). We add 1,2,3,4 after the dependent variables to represent the corresponding time windows.
} 
and zero if none of these analysts visit firm $i$ in the subsequent week (two weeks, three weeks, four weeks). Our main variable of interest, Peervisit $t_{i .} \times$ Post $_{i, t}$, captures how non-visiting analysts change attention allocated to a non-visited firm when a greater proportion of its industry peers host visits from the pre-period (2009-2011) to the post-period (2013-2015).

We also examine the impact of the timely disclosure requirement on the informational efficiency of visited firms as well as non-visited firms. We follow the literature and use return synchronicity to measure the extent to which stock prices reflect firm-specific information (Durnev et al., 2004; Piotroski and Roulstone, 2004; Israeli et al., 2017). We follow the same DiD research design and employ the following regressions:

$$
\begin{aligned}
\text { SYNCH }_{i, t}= & \alpha+\beta_{1} \text { Dvisit }_{i, t}+\beta_{2} \text { Post }_{i, t}+\beta_{3} \text { Dvisit }_{i, t} \times \text { Post }_{i, t} \\
& +\beta_{4} \text { Other Controls }+\varepsilon_{i, t}, \\
\text { SYNCH }_{i, t}= & \alpha+\beta_{1} \text { Peervisit }_{i, t}+\beta_{2} \text { Post }_{i, t}+\beta_{3} \text { Peervisit }_{i, t} \times \text { Post }_{i, t} \\
& +\beta_{4} \text { Other Controls }+\varepsilon_{i, t} .
\end{aligned}
$$

$\mathrm{SYNCH}_{i, t}$ is the stock return synchronicity for firm $i$ in the subsequent week (two weeks, three weeks, or four weeks). It is calculated as $\log \left(\frac{R_{i, t}^{2}}{1-R_{i, t}^{2}}\right)$, with $R_{i, t}^{2}$ from the firm-specific regression:

$$
\operatorname{RET}_{i, t}=\alpha+\beta_{1} \operatorname{MKTRET}_{t}+\beta_{2} \operatorname{MKTRET}_{t-1}+\beta_{3} \operatorname{INDRET}_{t}+\beta_{4} \operatorname{INDRET}_{t-1}+\varepsilon_{i, t},
$$

where $R E T_{i, t}, M_{K T R E T_{i, t}}$, and INDRET $T_{i, t}$ are daily stock-, market-, and industry-level returns, respectively. For example, when we calculate the synchronicity for firm $i$ during the two weeks subsequent to week $t$, we calculated $R_{i, t}^{2}$ by using the daily stock-, market-, and industry-level returns during the two weeks subsequent to week $t$.

Following the literature on analysts, we include several control variables (see the Appendix 1 for details): firm size (Size), leverage (Leverage), return on assets (ROA), market-to-book ratio $(M B)$, large blockholder ownership (Top1), state-owned enterprise or not (SOE), trading volume 
$(T V)$, stock return (Return), stock return volatility (STD), and number of following analysts (Analyst). In order to mitigate the endogenous concerns caused by reverse causality, we use lagged control variables in the regression. We also include firm fixed effects and year-week fixed effects to control for differences in analysts' attention allocation in different year-weeks and across different firms. To alleviate concerns about residual serial correlation and adjusted for heteroscedasticity, we two-way cluster standard errors at the firm level and firm-week level. The results are qualitatively similar if we cluster standard errors at the firm level.

\subsection{Sample Selection and Descriptive Statistics}

We use the data on public companies listed in SZSE in 2009-2011 and 2013-2015 as pre and post-period samples, respectively. We exclude the observations before 2009 as the disclosure of corporate site visits in the regular periodic reports can be incomplete before 2009 (Han et al., 2018), and exclude the observations in 2012 in case there was some delay in adopting the timely disclosure requirement. In addition, we exclude firms that had no or poor disclosures about site visits before 2012. ${ }^{21} \mathrm{We}$ exclude firm-weeks without any market trading activities (within that week or during one of the following four weeks) to avoid the confounding factors such as public holidays and trading suspension. We also exclude firm-weeks within 4 weeks prior to periodic reports because site visits close to the periodic reporting dates had been relatively timely disclosed before 2012. We retain firms with observations available in both the pre and post periods.

We obtain data on investor relation activities after July 2012 from the China Listed Firm's Investor Relations Database under the CSMAR database. For investor relation activities before

\footnotetext{
${ }^{21}$ Firms listed on the SME and GEM boards were not mandated to disclose private meetings before 2012. Therefore, in the pre-period, no disclosure by a firm might be due to the fact that it does not have private meetings or it hosts private meetings but does not disclose them. We drop these observations to avoid the confusing interpretation. We also drop the observations when the firm did not disclose the visiting dates in the pre-period.
} 
July 2012, we use the data from the Corporate Site Visit Database (CSVD) developed by Datago Technology Limited, which collects site visiting records disclosed in firms' periodic reports. For our main analysis, we only keep site visit activities with analysts, which is consistent with other studies (e.g., Cheng et al, 2016; Han et al., 2018). ${ }^{22}$ The other variables, including analyst forecasts, star analysts, financial reports, daily returns, and trading volumes are all from the CSMAR database. We winsorize continuous variables at the $1 \%$ and $99 \%$ levels.

The resulting final sample includes 169,496 firm-weeks and 821 distinct firms. Table 1 reports the descriptive statistics. In Panel A, we report the time trend for corporate site visits. Generally, there are more weeks with site visits, and more visits and visiting weeks per broker over time. There are fewer visits per week and more brokers per visit during the post period than the pre period, which might be consistent with the explanation that firms combine multiple visiting requests into one visit. We discuss this further in Section 5.1.

Panel B reports the summary statistics of the variables we use in the paper. We find that $7.3 \%$ of the firm-week observations are visited firm-weeks and $58.4 \%$ of the sample falls in the post-period. The average $R O A$ and market-to-book ratio are $3.8 \%$ and 3.708 , respectively.

\section{[Insert Table 1 Here]}

\section{Main Results}

\subsection{Attention Allocated to Visited Firms}

Our main analysis compares the change in attention allocated by analysts to visited firms relative to non-visited firms following the timely disclosure requirement in 2012. To do so, we

\footnotetext{
${ }^{22}$ In firms' meeting records, most of investor relation activities with either analysts or funds are related to "site visits" or "private meetings." We exclude all non-site-visit events, such as telephone interviews, email exchanges, non-deal roadshows, investor conferences, and annual broker conferences (Cheng et al. 2016).
} 
estimate equation (1), and report the results in Table 2.

[Insert Table 2 Here]

Columns (1)-(4) report the change in attention allocated to visited firms relative to nonvisited firms during subsequent one week (DvisitF1), two weeks (DvisitF2), three weeks (DvisitF3), and four weeks (DvisitF4), respectively. Across the four columns, the coefficients on Dvisit are positive, indicating that on average, when a firm hosts site visits during a week, it is more likely to host site visits during subsequent weeks. The coefficients on the variable of interest, Dvisit $\times$ Post are negative and statistically significant, suggesting that following the timely disclosure requirement, non-visiting analysts reduce the tendency to visit firms that have hosted site visits relative to firms that have not hosted site visits. The results are consistent with the conjecture that when firms are required to make more timely disclosures, non-visiting analysts tend to reduce attention allocated to visited firms relative to non-visited firms. The effects we document are economically significant. For example, compared to a non-visited firm during the same week, analysts decrease their propensity to visit a visited firm during the next four weeks by 0.071 , which equals approximately $33 \%$ of the sample average.

Our key identifying assumption for the consistency of the DiD research design is that the parallel trends assumption is satisfied. That is, in the absence of treatment (the 2012 timely disclosure requirement), visited (treated) and non-visited (control) firm-weeks should exhibit parallel trends in the outcome variable, i.e., Attention. While the parallel trend assumption is not directly testable (since the trend in Attention absent the 2012 timely disclosure requirement is not observable), similar to other DiD studies we examine the trend in Attention prior to the event of interest (Roberts and Whited, 2013). In Figure 1 we plot the difference between DVisitF1 for each year between 2009 and 2015 for visited and non-visited firm-weeks. To do so, we re-run equation 
(1) modified to include separate indicators to capture each year in 2009-2011 and 2013-2015, respectively (interacted with Dvisit, similar to the indicator Post). We use 2011 as the benchmark year, so each point on the graph shows the difference between visited and non-visited firm-weeks relative to the difference in 2011. In Figure 1, there is no evidence showing that visited and nonvisited firm-weeks have different trends leading up to 2012, whereas the tendency of subsequent visit of visited firm-weeks appears to decrease relative to non-visited firm-weeks after 2012. ${ }^{23}$ Overall, the parallel trend assumption seems reasonable in our setting.

\subsection{Cross-sectional Analyses}

The results in Table 2 suggest a reduction in analyst attention allocated to visited firms relative to non-visited firms by non-visiting analysts following the timely disclosure requirement. These results are consistent with the conjecture that the disclosure reveals the information advantage of visiting analysts so non-visiting analysts would likely reduce their attention allocated to the visited firm. In this section we examine whether the documented differential change in attention allocation varies with the degree of visiting analysts' information advantage. We predict that non-visiting analysts would be more likely to reduce attention allocated to visited firms if visiting analysts gain a stronger information advantage. Lacking a direct measure of such information advantage, we use three proxies to capture the extent to which visiting analysts process and learn information from the site visits. We expect the main results to be more pronounced if during the most recent year at least one visiting analyst has (i) visited the visited firm, (ii) covered the visited firm, or (iii) been rated as a star analyst.

To test these conjectures, we estimate three regressions:

$$
\text { Attention }_{i, t}=\alpha+\beta_{1} \text { Dvisit_Recent }_{i, t}+\beta_{2} \text { Dvisit_NonRecent }_{i, t}+\beta_{3} \text { Post }_{i, t}
$$

\footnotetext{
${ }^{23}$ When we use DVisitF2, DvisitF3, or DvisitF4 to plot the parallel trend, the inference remains the same.
} 


$$
+\beta_{4} \text { Dvisit_Recent }_{i, t} \times \text { Post }_{i, t}+\beta_{5} \text { Dvisit_NonRecent }_{i, t} \times \text { Post }_{i, t}+\varepsilon_{i, t},
$$

where Dvisit_Recent equals one if at least one visiting analyst visits firm $i$ during the most recent year (past 52 weeks), and zero otherwise, and Dvisit_NonRecent equals one if there is no visiting analyst with visiting history during the most recent year, and zero otherwise.

$$
\begin{aligned}
\text { Attention }_{i, t}=\alpha & +\beta_{1} \text { Dvisit_Follow }_{i, t}+\beta_{2} \text { Dvisit_NonFollow }_{i, t}+\beta_{3} \text { Post }_{i, t} \\
& +\beta_{4} \text { Dvisit_Follow }_{i, t} \times \text { Post }_{i, t}+\beta_{5} \text { Dvisit_NonFollow }_{i, t} \times \text { Post }_{i, t}+\varepsilon_{i, t},
\end{aligned}
$$

where Dvisit_Follow equals one if at least one visiting analyst issues an earnings forecast for firm $i$ during the most recent year, and zero otherwise, and Dvisit_NonFollow equals one if no visiting analyst issues a forecast for firm $i$ during the most recent year, and zero otherwise.

$$
\begin{aligned}
\text { Attention }_{i, t}= & \alpha+\beta_{1} \text { Dvisit_STAR }_{i, t}+\beta_{2} \text { Dvisit_NONSTAR }_{i, t}+\beta_{3} \text { Post }_{i, t} \\
& +\beta_{4} \text { Dvisit_STAR }_{i, t} \times \text { Post }_{i, t}+\beta_{5} \text { Dvisit_NONSTAR }_{i, t} \times \text { Post }_{i, t}+\varepsilon_{i, t}
\end{aligned}
$$

where Dvisit_STAR equals one if at least one visiting analyst is a star analyst during the most recent year, and zero otherwise, and Dvisit_NONSTAR equals one if no visiting analyst is a star analyst during the most recent year, and zero otherwise. A star analyst is an analyst who has been rated as a "star analyst" by New Fortune Magazine.

The results are reported in Table 3. Panels A, B, and C report the results based on whether or not at least one visiting analyst visits the visited firm, issues an earnings forecast for the visited firm, or is rated as a star analyst, respectively, during the most recent year. In Panel A, in columns (1)-(4), the coefficients on Dvisit_Recent $\times$ Post and Dvisit_NonRecent $\times$ Post are all negative and significant, indicating that for both groups, following the timely disclosure requirement, nonvisiting analysts reduce their attention allocated to the visited firms relative to non-visited firms. When we compare the two coefficients on Dvisit_Recent $\times$ Post and Dvisit_NonRecent $\times$ Post, the F-test results indicate the coefficients are significantly different for DvisitF2, DvisitF3, and DvisitF4. The results suggest that our main results are more pronounced for visited firms that 
involved analysts who have visited those firms recently. In Panel B, in columns (1)-(4), the coefficients on Dvisit_Follow $\times$ Post and Dvisit_NonFollow $\times$ Post are all negative and significant (except for DvisitF1 for analysts who have not recently visited the firm), indicating that for both groups, following the timely disclosure requirement, non-visiting analysts reduce their attention allocated to the visited firms relative to non-visited firms. When we compare the two coefficients on Dvisit_Follow $\times$ Post and Dvisit_NonFollow $\times$ Post, the F-test results indicate the coefficients are significantly different at the $1 \%$ level. The results suggest that our main results are more pronounced for visited firms that involved analysts who have covered those firms recently. In Panel C, in columns (1)-(4), the coefficients on Dvisit_Star $\times$ Post and Dvisit_NonStar $\times$ Post are all negative and significant, indicating that for both groups, following the timely disclosure requirement, non-visiting analysts reduce their attention allocated to visited firms relative to nonvisited firms. When we compare the two coefficients on Dvisit_Star $\times$ Post and Dvisit_NonStar $\times$ Post, the F-test results indicate the coefficients are significantly different at the $1 \%$ level. The results suggest that our main results are more pronounced for visited firms that involved star analysts.

To summarize, the cross-sectional results are consistent with our prediction that following the timely disclosure requirement, non-visiting analysts are more likely to reduce attention allocated to visited firms that involve analysts who potentially have a stronger information advantage due to their expertise to process and learn information.

[Insert Table 3 Here]

\subsection{Attention Allocated to Non-visited Firms}

If non-visiting analysts reduce attention to visited firms, then the next question is where they shift their attention. To examine this question, we estimate equation (2) and report the results 
in Table 4. The coefficients on Peervisit are positive and significant, suggesting that when a greater proportion of the non-visited firm's industry peers are visited during a week, it is more likely to be visited during subsequent weeks.

The coefficients on the variable of interest, Peervisit $\times$ Post, are positive and statistically significant, suggesting that following the timely disclosure requirement, a non-visited firm experiences a relatively larger increase in analyst attention during subsequent weeks when a larger proportion of its industry peers hosted visits.

One concern is that the disclosure of a visit might reveal the existence of industry-level, value-relevant information, as prior studies find that firm disclosures contain information that is useful to value industry-peer firms (e.g., Foster, 1981; Bushee and Leuz, 2005; Shroff et al., 2017). It may well explain the results in Table 4, since it is more likely that there is industry-level information when a larger proportion of a firm's industry peer firms are visited. Once the visits are publicly disclosed, non-visiting analysts might increase attention to these non-visited firms due to the revealed existence of industry-level information. However, it is unclear how the existence of industry-level information could explain the reduction in attention allocated to visited firms as shown in Table 2, as non-visiting analysts should also increase attention paid to visited firms. Untabulated results also suggest that the main results in Table 2 do not vary based on the extent to which a visit reflects the existence of industry-level information, as captured by the average unsigned abnormal returns of peer firms to each visit.

[Insert Table 4 Here]

\section{Informational Efficiency of Firms}

Next, we examine the effects of the timely disclosure on firm informational efficiency after analysts shift attention from visited firms to non-visited firms. We use stock return synchronicity 
to proxy for informational efficiency as it reflects the extent to which stock prices reflect firmspecific information.

We examine the effects on stock return synchronicity of visited firms. On the one hand, the timely disclosure requirement might enable investors to know the content of the meetings in a timelier manner, increasing informational efficiency. On the other hand, non-visiting analysts might reduce attention allocated to the visited firms, which might worsen the informational efficiency of the visited firms. To investigate this question, we estimate regression equation (3) and report the results in Table 5. The coefficients on the variable of interest, Dvisit $\times$ Post are marginally significant (for $S Y N C H 2$ and $S Y N C H 4$ ) or insignificant (for $S Y N C H 3$ ), suggesting that the requirement might marginally improve the informational efficiency of the visited firms. ${ }^{24}$

\section{[Insert Table 5 Here]}

We then examine the effects on stock price synchronicity of non-visited firms. The results in Section 4.3 suggest that following the timely disclosure requirement, non-visiting analysts increase attention to a non-visited firm if more of its industry peer firms host site visits, which could improve the informational efficiency of the non-visited firm. We estimate regression equation (4) and report the results in Table 6. The coefficients on the variable of interest, Peervisit $\times$ Post are negative and statistically significant, suggesting that subsequent to the timely disclosure requirement, as more peer firms host site visits, the non-visited firm experiences a larger increase in informational efficiency as reflected in a reduction in return synchronicity.

\section{[Insert Table 6 Here]}

The results imply that from the pre- to the post-period, the informational efficiency of a visited firm is marginally improved, while the informational efficiency of a non-visited firm gets

\footnotetext{
${ }^{24}$ For the synchronicity during the subsequent week, there are five observations and five estimated coefficients (including the intercept) per firm so we cannot estimate the $R_{i, t}^{2}$ and synchronicity for the subsequent week (SYNCHI).
} 
improved as a larger proportion of its industry peers host visits. Therefore, by influencing analysts' attention allocation, the timely disclosure of corporate site visits has positive spillover effects on peer firms' informational efficiency.

\section{Additional Analyses}

\subsection{Alternative Explanation: Firms Combining Visits}

Although most site visits are initiated by analysts or investors and firms are required to accommodate their requests as suggested in the "Guidelines of Investor Relations Management" issued by the SZSE, firms may negotiate with visitors on the visiting dates if the requested time is not convenient (Cheng et al., 2018). The timely disclosure requirement might increase firms' compliance costs, so firms may combine several visiting requests with different requested dates (possibly in different weeks) and accommodating them on the same date. In this way, instead of recording and disclosing several times (possibly over several weeks) the visiting information within two days after each visit, firms only need to do it for once. This scenario might be an alternative explanation for our results, although it may be arguable whether analysts and investors are willing to accommodate firms' visit combination requests and whether the increase in compliance costs is significant enough. We attempt to mitigate this concern in several ways. First, during a week, when multiple analysts visit a firm, we expect it is more likely that the firm combined visits to reduce their compliance burden. We therefore examine whether our results are driven by firm-week observations that involve multiple analysts. We estimate the following regression:

$$
\begin{aligned}
\text { Attention }_{i, t}= & \alpha+\beta_{1} \text { Dvisit_Multiple }_{i, t}+\beta_{2} \text { Dvisit_Single }_{i, t}+\beta_{3} \text { Post }_{i, t} \\
& +\beta_{4} \text { Dvisit_Multiple }_{i, t} \times \text { Post }_{i, t}+\beta_{5} \text { Dvisit_Single }_{i, t} \times \text { Post }_{i, t}+\varepsilon_{i, t},
\end{aligned}
$$


where Dvisit_Multiple equals one if there are multiple visiting analysts for firm $i$ during week $t$, and zero otherwise, and Dvisit_Single equals one if there is only one visiting analyst for firm $i$ during week $t$, and zero otherwise.

Panel A of Table 7 shows that the coefficients on Dvisit_MultiplexPost and Dvisit_Single $\times$ Post are both negative and significant, indicating that regardless of whether or not the firm is visited by more than one analyst, following the timely disclosure requirement, nonvisiting analysts reduce attention allocated to visited firms relative to non-visited firms. Although the differences between the two coefficients are significant for DvisitF2, DvisitF3, and DvisitF4, which suggests our results are stronger when multiple analysts visit the firm, our results cannot be fully explained by this alternative explanation as the coefficients on Dvisit_Single $\times$ Post are negative and significant.

Additionally, in China it is the board secretary who is in charge of public disclosure compliances. A board secretary is responsible for preparing board meetings, shareholder meetings, as well as dealing with information disclosures. Therefore, the busier a board secretary is, it is more likely that this individual combines several visiting requests into one visit after the timely disclosure requirement. If our results are driven by the alternative explanation, our results should be stronger with a busy board secretary. We expect a board secretary is busy when the number of board meetings is above the sample median. ${ }^{25}$ We estimate the regression (1) based on whether a board secretary is busy or not and report the results in Panel B of Table 7. The differences in the

\footnotetext{
${ }^{25}$ To mitigate the concern that the number of board meetings might have changed following the mandated requirement, we calculate the sample median based on the data prior to 2012 .
} 
coefficients on Dvisit $\times$ Post are not statistically significant between firms with and without a busy board secretary, which suggests our results are not driven by firms with a busy board secretary. ${ }^{26}$

$$
\text { [Insert Table } 7 \text { Here] }
$$

In summary, our main results are not likely fully driven by the conjecture that firms tend to combine visits after the timely disclosure requirement. Notwithstanding the above tests, to the extent that these tests have limitations to capture the tendency of firms to combine visits, this is a caveat of our study.

\subsection{Site Visits by Mutual Funds}

Our main results suggest that the timely disclosure requirement reveals visiting analysts' information advantage, so non-visiting analysts reduce attention allocated to visited firms relative to non-visited firms. It is an empirical question whether this channel could also be applied to mutual funds as another important market participants who usually visit firms. We test this by using the visits conducted by analysts, mutual funds, or both and re-run equation (1). The coefficients on Dvisit $\times$ Post are all negative and significant, as shown in Panel A of Table 8. We also re-run equation (1) and only consider visits by mutual funds. The coefficients on Dvisit $\times$ Post are all negative and significant, as shown in Panel B of Table 8.

[Insert Table 8 Here]

\subsection{Alternative Measures of Analysts' Attention}

In this section, we use an alternative measure to proxy for analysts' attention. Specifically, we re-estimate equation (1), but instead of using the tendency of subsequent site visits as a proxy

\footnotetext{
${ }^{26}$ Because we can define busy secretaries for both visited and non-visited firms, we run separate regressions for secretaries that are busy and those that are not and perform chi-squared tests for the differences between the coefficients in the two regressions.
} 
for analysts' attention, we use the tendency to issue forecast revisions. ${ }^{27}$ The results are reported in Table 9. In columns (1)-(4), the coefficients on Dvisit $\times$ Post are negative and significant, suggesting that non-visiting analysts reduce attention allocated to visited firms following the timely disclosure requirement. Therefore, by using the tendency of issuing forecast revisions as an alternative measure of analyst attention, we corroborate our main results in Table 2.

$$
\text { [Insert Table } 9 \text { Here] }
$$

\subsection{Robustness Test}

In this section, we check the robustness of our results. Our main research design is at the firm-week level. We re-estimate equation (1) on the firm-week-analyst level as a robustness check. To identify the potential firm-analyst pairs, for each firm-week observation, we keep analysts who issue forecasts during the most recent year. ${ }^{28}$ In the regression we also include the characteristics of analysts as additional control variables, including the number of analysts within the analyst's brokerage house (Brokersize), the length of the coverage history (Firmexperience), and the number of firms covered by the analyst (Companies). ${ }^{29}$ We report the results in Table 10 . The results are

\footnotetext{
${ }^{27}$ We use the tendency of site visits to proxy for analysts' attention in our main results because site visits capture an explicit commitment of time and resources (So et al., 2020), while the tendency to issue forecast revision is an implicit outcome of analysts' attention allocation.

${ }^{28}$ Every year we exclude firms or analysts without any site visits and only keep firm-analysts with at least one observation for both periods before and after 2012. Similar to our main analysis, for each visited firm-week observation, we exclude visiting analysts.

${ }^{29}$ Most firms do not report the names of the visiting analysts before 2012, so we make some assumptions to conduct this additional analysis. We measure Firmexperience and Companies by assuming the analyst in a brokerage who has covered the firm during the most recent year is the visiting analyst as a brokerage typically has one analyst covering a specific firm (Cheng et al., 2018). In case there are multiple analysts covering the firm within the brokerage, we use the maximum of these analysts to calculate the additional control variables. We use the logarithm of the three additional control variables in our regression.
} 
qualitatively similar, i.e., non-visiting analysts reduce attention allocated to non-visited firms, following the timely disclosure requirement. ${ }^{30}$

[Insert Table 10 Here]

\section{Conclusion}

In this paper, we investigate the consequences of increased transparency of corporate site visits on analysts' attention allocation. We use the 2012 timely disclosure requirement of corporate site visits by the SZSE in China in 2012 as a setting. We find that analysts who do not participate in the disclosed site visits switch their attention from firms involved to other peer firms in the same industry. We also document a greater improvement in informational efficiency when a greater proportion of a firm's peer firms host visits without compromising the informational efficiency of visited firms, suggesting that such transparency has positive spillover effects by influencing analysts' attention allocation. By documenting these results, our paper contributes to the literature on attention allocation of analysts (e.g., Blankespoor et el., 2020) and the spillover effects of firms' public disclosure (e.g., Leuz and Wysocki, 2016). Our paper also contributes to the policy debate regarding the disclosure of corporate site visits. Despite the potential disclosure costs directly imposed on firms, firms collectively can benefit from this disclosure requirement due to the positive spillover effects.

\footnotetext{
${ }^{30}$ One challenge to this test is how to identify analyst-firm pairs. It is not plausible for us to match all the analysts with every single firm, as the proportion of the observations with Dvisit=1 would be too small. We thus identify analysts who have issued forecasts during the most recent year as analysts who would potentially visit the firm. However, we acknowledge that we may not count for analysts who visit the firm before they issue any forecasts, so we mostly rely on the firm-week-level analyses complemented by the firm-week-analyst-level analyses as a robustness check.
} 


\section{References}

Bengtzen, M., 2016. EU and UK investment disclosure liability: at cross purposes?. Capital Markets Law Journal, 11(3), pp.429-441.

Blankespoor E., deHaan, E., and Marinovic, I., 2019. Disclosure processing costs, investors' information choice, and equity market outcomes: a review. Forthcoming, Journal of Accounting and Economics.

Bowen, R. M. and Dutta, S., Tang, S. and Zhu, P., 2019. Does stricter disclosure regulation of private meetings improve the information environment?. Working Paper.

Bradshaw, M., 2011. Analysts' forecasts: what do we know after decades of work? Working Paper, Boston College.

Breuer, M., Hombach, K. and Müller, M.A., 2018. When you talk, I remain silent: Spillover effects of peers' mandatory disclosures on firms' voluntary disclosures. Working Paper.

Brown, L., Call, A., Clement, M. and Sharp, N., 2015. Inside the "black box" of sell-side financial analysts. Journal of Accounting Research, 53(1), pp.1-47.

Bushee, B., and Leuz, C., 2005. Economic consequences of SEC disclosure regulation: evidence from the OTC bulletin board. Journal of Accounting and Economics 39, pp.233-264.

Cheng, Q., Du, F., Wang, X. and Wang, Y., 2016. Seeing is believing: analysts' corporate site visits. Review of Accounting Studies, 21(4), pp.1245-1286.

Cheng, Q., Du, F., Wang, B.Y. and Wang, X., 2019. Do corporate site visits impact stock prices?. Contemporary Accounting Research, 36(1), pp.359-388.

Clement, M.B. and Tse, S.Y., 2005. Financial analyst characteristics and herding behavior in forecasting. The Journal of finance, 60(1), pp.307-341.

Crawford, S.S., Roulstone, D.T. and So, E.C., 2012. Analyst initiations of coverage and stock return synchronicity. The Accounting Review, 87(5), pp.1527-1553.

De George, E.T., Phan, M. and Stoumbos, R.C., 2019. Financial Reporting Frequency and the Allocation of Investor Attention. Available at SSRN 3433828.

Durnev, A., Morck, R., Yeung, B. and Zarowin, P., 2003. Does greater firm-specific return variation mean more or less informed stock pricing? Journal of Accounting Research, 41, pp.797-836.

Driskill, M., Kirk, M.P. and Tucker, J.W., 2020. Concurrent Earnings Announcements and Analysts' Information Production. The Accounting Review, 95(1), pp.165-189.

Dunn, K. and Nathan, S., 2005. Analyst Industry Diversification and Earnings Forecast Accuracy. The Journal of Investing, 14(2), pp.7-14.

Foster, G., 1981. Intra-industry information transfers associated with earnings releases. Journal of Accounting and Economics 3, pp.201-232. 
Grossman, S.J. and Stiglitz, J.E., 1980. On the impossibility of informationally efficient markets. The American Economic Review, 70(3), pp.393-408.

Han, B., Kong, D. and Liu, S., 2018. Do analysts gain an informational advantage by visiting listed companies?. Contemporary Accounting Research, 35(4), pp.1843-1867.

Harford, J., Jiang, F., Wang, R. and Xie, F., 2018. Analyst career concerns, effort allocation, and firms' information environment. The Review of Financial Studies, 32(6), pp.2179-2224.

Hirshleifer, D., Levi, Y., Lourie, B. and Teoh, S.H., 2019. Decision fatigue and heuristic analyst forecasts. Journal of Financial Economics, 133(1), pp.83-98.

Hong, H. and Kacperczyk, M., 2010. Competition and bias. The Quarterly Journal of Economics, 125(4), pp.1683-1725.

Israeli, D., Lee, C. and Sridharan, S., 2017. Is there a dark side to exchange traded funds? An information perspective. Review of Accounting Studies, 22, pp.1048-1083.

Jegadeesh, N. and Kim, W., 2010. Do analysts herd? An analysis of recommendations and market reactions. The Review of Financial Studies, 23(2), pp.901-937.

Kahneman, D., 1973. Attention and effort (Vol. 1063). Englewood Cliffs, NJ: Prentice-Hall.

Leuz, C. and Wysocki, P., 2016. The economics of disclosure and financial reporting regulation: evidence and suggestions for future research. Journal of Accounting Research, 54(2), pp.525-622.

Li, Z., Wong, T.J. and Yu, G., 2020. Information dissemination through embedded financial analysts: Evidence from China. The Accounting Review, 95(2), pp.257-281.

Merkley, K., Michaely, R. and Pacelli, J., 2017. Does the scope of the sell-side analyst industry matter? An examination of bias, accuracy, and information content of analyst reports. The Journal of Finance, 72(3), pp.1285-1334.

Piotroski, J. and Roulstone, B., 2004. The influence of analysts, institutional investors, and insiders on the incorporation of market, industry, and firm-specific information into stock prices. The Accounting Review, 79(4), pp.1119-1151.

Shroff, N., Verdi, R. and Yost, B., 2017. When does the peer information environment matter? Journal of Accounting and Economics, 64, pp.183-214.

Sims, C.A., 2003. Implications of rational inattention. Journal of monetary Economics, 50(3), pp.665-690.

Sims, C.A., 2010. Rational inattention and monetary economics. In Handbook of monetary Economics (Vol. 3, pp. 155-181). Elsevier.

So, E., Wang, R. and Zhang, R., 2020. Meet Markets: Investor Meetings and Expected Returns. Working paper. 
Solomon, D. and Soltes, E., 2015. What are we meeting for? The consequences of private meetings with investors. The Journal of Law and Economics, 58(2), pp.325-355.

Soltes, E., 2014. Private interaction between firm management and sell-side analysts. Journal of Accounting Research, 52(1), pp. 245-272.

Van Nieuwerburgh, S. and Veldkamp, L., 2009. Information immobility and the home bias puzzle. The Journal of Finance, 64(3), pp.1187-1215.

Van Nieuwerburgh, S. and Veldkamp, L., 2010. Information acquisition and under-diversification. The Review of Economic Studies, 77(2), pp.779-805.

Veldkamp, L.L., 2011. Information choice in macroeconomics and finance. Princeton University Press. 


\section{Appendix 1 Disclosure of Corporate Site Visits by Tsinghua Unis Co., Ltd}

Before 2012, firms are required to disclose private meeting events in their regular periodic reports. Below is an extract from the 2010 annual report released on March 31, 2011.

\begin{tabular}{lllll}
\hline Time & Location & Format & Visitors & Topics \\
\hline $2 / 12 / 2010$ & $\begin{array}{l}\text { Planning } \\
\text { Department }\end{array}$ & $\begin{array}{l}\text { Site } \\
\text { visit }\end{array}$ & $\begin{array}{l}\text { Yinhe Securities } \\
\text { client manager }\end{array}$ & $\begin{array}{l}\text { Company basic operations } \\
\text { and direction of future } \\
\text { development }\end{array}$ \\
\hline $3 / 1 / 2010$ & $\begin{array}{l}\text { Planning } \\
\text { Department }\end{array}$ & $\begin{array}{l}\text { Site } \\
\text { visit }\end{array}$ & $\begin{array}{l}\text { Xiangcai Securities } \\
\text { analyst }\end{array}$ & $\begin{array}{l}\text { Company basic operations } \\
\text { and direction of future } \\
\text { development }\end{array}$ \\
\hline $10 / 12 / 2010$ & $\begin{array}{l}\text { Planning } \\
\text { Department }\end{array}$ & $\begin{array}{l}\text { Site } \\
\text { visit }\end{array}$ & $\begin{array}{l}\text { Huatai Securities } \\
\text { analyst }\end{array}$ & $\begin{array}{l}\text { Company basic operations } \\
\text { and direction of future } \\
\text { development }\end{array}$ \\
\hline $10 / 13 / 2010$ & $\begin{array}{l}\text { Planning } \\
\text { Department }\end{array}$ & $\begin{array}{l}\text { Site } \\
\text { visit }\end{array}$ & $\begin{array}{l}\text { Hongyuan Securities } \\
\text { analyst }\end{array}$ & $\begin{array}{l}\text { Company basic operations } \\
\text { and direction of future } \\
\text { development }\end{array}$ \\
\hline $11 / 10 / 2010$ & $\begin{array}{l}\text { Planning } \\
\text { Department }\end{array}$ & $\begin{array}{l}\text { Site } \\
\text { visit }\end{array}$ & $\begin{array}{l}\text { Fangzheng } \\
\text { Securities analyst }\end{array}$ & $\begin{array}{l}\text { Company basic operations } \\
\text { and direction of future } \\
\text { development }\end{array}$ \\
\hline
\end{tabular}

After 2012, firms are required to disclose private meeting events within two days on the investor service platform: HudongYi (http://irm.cninfo.com.cn/szse/). Below is the disclosure by the firm on HudongYi in 2013. All the disclosures are made within two days after each visit.

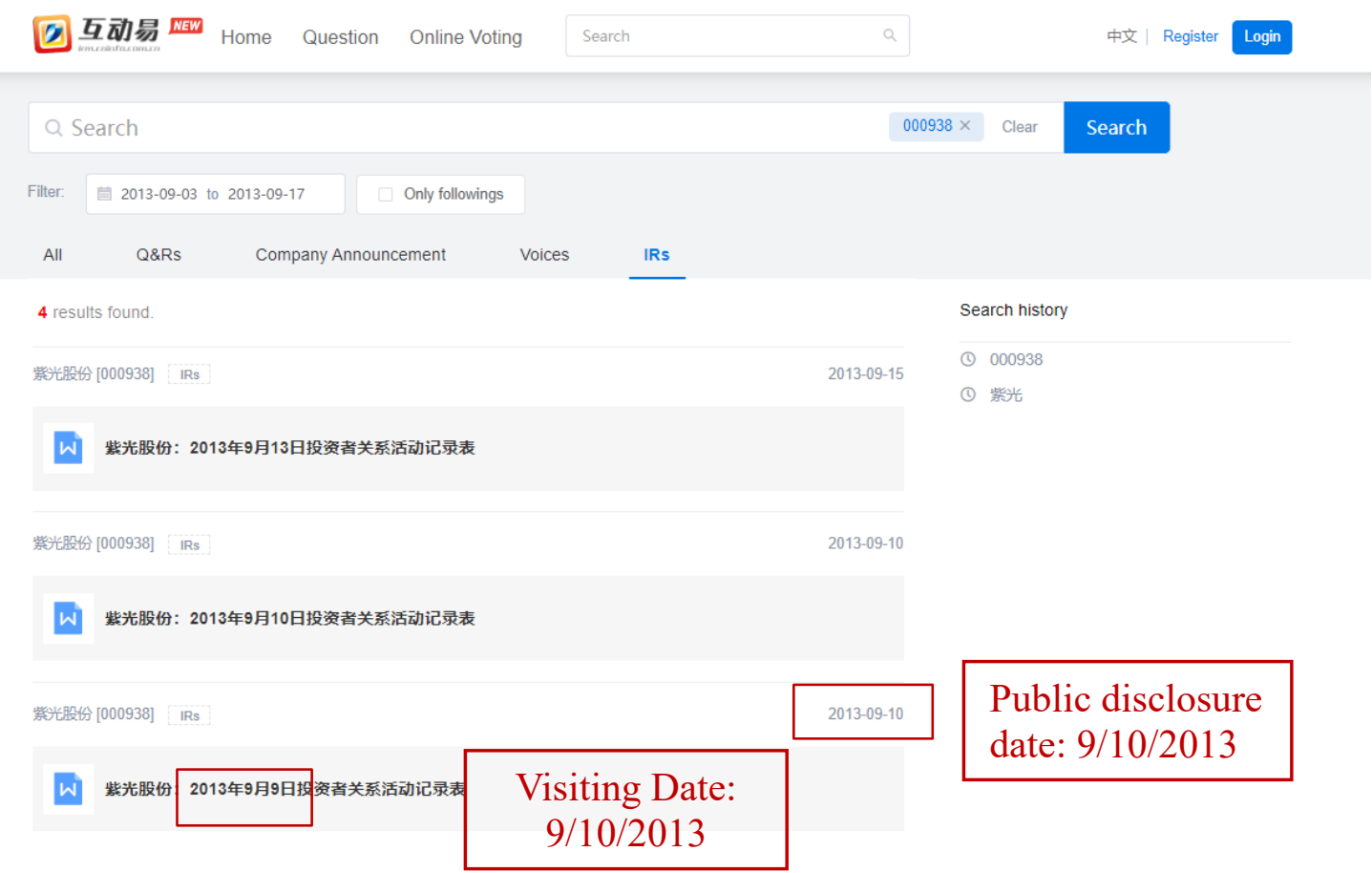

Below is the standard form disclosed by the firm. 
Stock code: $000938 \quad$ Company Name: Unis

The Record of Unis Investor Relations

\begin{tabular}{|c|c|}
\hline $\begin{array}{l}\text { Type of } \\
\text { Investors } \\
\text { Relation } \\
\text { Activities }\end{array}$ & $\begin{array}{l}\checkmark \text { Specific entity investigation } \\
\square \text { Analyst conference } \\
\square \text { Media interview } \quad \square \text { Performance conference } \\
\square \text { Press conference } \quad \square \text { Road show } \\
\square \text { Site visit } \\
\square \text { Other (Please explain) }\end{array}$ \\
\hline $\begin{array}{l}\text { Meeting } \\
\text { Participants }\end{array}$ & Caifu Liang Securities, Huihui Xu, Lingtian Feng, Sijing Chen \\
\hline Time & $9 / 10 / 2013$ \\
\hline Location & Meeting room of Unis \\
\hline $\begin{array}{l}\text { Management } \\
\text { Attended }\end{array}$ & $\begin{array}{l}\text { Board Secretary Wei Zhang } \\
\text { Deputy Manager of Securities Department Meng Ge }\end{array}$ \\
\hline $\begin{array}{l}\text { Main Topics of } \\
\text { the Meeting }\end{array}$ & $\begin{array}{l}\text { Company basic operations and direction of future development: } \\
\text { 1. Basic Operations } \\
\text { Our main business is divided into } 3 \text { categories (1) own-brand information } \\
\text { electronic products represented by digital imaging products (2) IT services } \\
\text { such as software and system integration (3) value-added distribution business. } \\
\text { In the field of self-owned brands, our company is constantly moving } \\
\text { towards a provider of comprehensive industry solutions for digital input. On } \\
\text { the basis of the complete product lines of scanners and HD shooting products } \\
\text { as the core digital imaging hardware products, we continue to improve the } \\
\text { development and upgrade of digital imaging application software, and } \\
\text { establish a rich industry application platform to meet customers' needs in } \\
\text { image collection, data processing, classified storage, information extraction, } \\
\text { data interaction, etc. In terms of industry applications, in } 2012 \text { our company } \\
\text { launched a comprehensive management system for catering enterprises. This } \\
\text { system helps comprehensively manage the business, procurement, inventory, } \\
\text { financial management, employee management, etc. It has been promoted in the } \\
\text { Beijing area. } \\
\text { In the field of IT services, our company has many experiences and } \\
\text { advantages in many fields such as civil affairs, education, transportation, }\end{array}$ \\
\hline
\end{tabular}




\begin{tabular}{|c|c|}
\hline & $\begin{array}{l}\text { public security, radio and television, and other government agencies and } \\
\text { industries. While maintaining the stable development of the traditional } \\
\text { business, our company has completed the research and development of the } \\
\text { "Ziguang" cloud computing management platform, formed a regional e- } \\
\text { government cloud and SME service cloud platform, and can provide big data } \\
\text { cloud computing solutions. } \\
\text { In the field of value-added distribution, our company cooperates with } \\
\text { well-known domestic and foreign brands such as HP, Dell, Lenovo, BenQ, } \\
\text { Samsung, etc. Our products cover mainstream IT products. We pay attention to } \\
\text { the application of modern management methods and has established a perfect } \\
\text { information management system. Our value-added distribution business is one } \\
\text { of the top domestic distribution service providers. } \\
2 \text {. Future Development after the M\&As } \\
\text { Our company will take this M\&A as an opportunity, through business and } \\
\text { resource integration to gradually achieve the strategic goal to become a full } \\
\text { service provider in the construction, operation, and maintenance or the modern } \\
\text { information systems. We have extensive synergies with Nengtong Technology } \\
\text { and Shenzhen Rongchuang Tianxia. The M\&A can amplify the resources in } \\
\text { customer, technology, marketing and service networks, enabling Unis to gain } \\
\text { first-mover advantages in could computing, IT operation and maintenance } \\
\text { services, mobile internet applications and big data processing, to further } \\
\text { expand the opportunities to improve the smart city business. }\end{array}$ \\
\hline $\begin{array}{l}\text { Attachments（if } \\
\text { yes) }\end{array}$ & No \\
\hline Date of record & $9 / 10 / 2013$ \\
\hline
\end{tabular}




\section{Appendix 2 Variable Definitions}

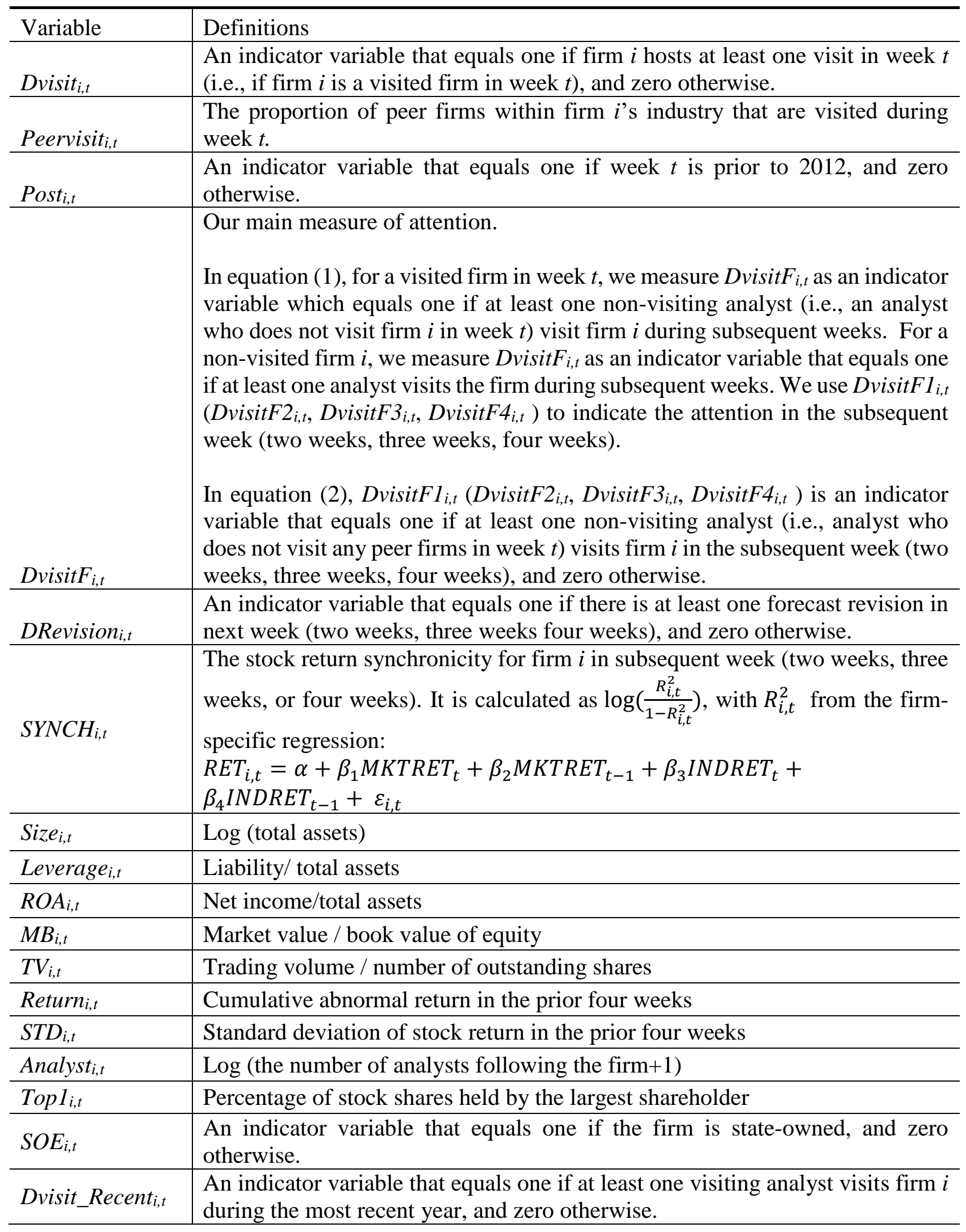




\begin{tabular}{l|l}
\hline $\begin{array}{l}\text { Dvisit_NonRece } \\
n t_{i, t}\end{array}$ & $\begin{array}{l}\text { An indicator variable that equals one if no visiting analyst who has visited firm } \\
i \text { during the most recent year, and zero otherwise. }\end{array}$ \\
\hline Dvisit_Follow $w_{i, t}$ & $\begin{array}{l}\text { An indicator variable that equals one if at least one visiting analyst issues } \\
\text { forecasts for firm } i \text { during the most recent year, and zero otherwise. }\end{array}$ \\
\hline $\begin{array}{l}\text { Dvisit_NonFollo } \\
w_{i, t}\end{array}$ & $\begin{array}{l}\text { An indicator variable that equals one if no visiting analyst issues forecasts firm } \\
i \text { during the most recent year, and zero otherwise. }\end{array}$ \\
\hline Dvisit_Star ${ }_{i, t}$ & $\begin{array}{l}\text { An indicator variable that equals one if at least one visiting analyst if a star } \\
\text { analyst during the most recent year, and zero otherwise. }\end{array}$ \\
\hline Dvisit_NonStar & $\begin{array}{l}\text { An indicator variable that equals one if no visiting analyst is a star analyst } \\
\text { during the most recent year, and zero otherwise. }\end{array}$ \\
\hline Dvisit_Multiple $i, t$ & $\begin{array}{l}\text { An indicator variable that equals one if the number of visiting analysts for firm } \\
i \text { during week } t \text { is larger than one, and zero otherwise. }\end{array}$ \\
\hline Dvisit_Single $e_{i, t}$ & $\begin{array}{l}\text { An indicator variable which equals one if there is only one visiting analyst for } \\
\text { firm } i \text { during week } t, \text { and zero otherwise. }\end{array}$ \\
\hline
\end{tabular}


Figure 1 Parallel Trend

This figure presents trends in differences of DvisitF1 between visited firm-weeks and non-visited firm-weeks over six years. To construct the figure, we re-run equation (1) modified to include separate indicators to capture each year in 2009-2011 and 20132015, respectively (interacted with Dvisit, similar to the indicator Post). We use 2011 as the benchmark year, so each point on the graph shows the difference between treated and control firm-weeks relative to 2011. DvisitF1 is an indicator variable that equals one if at least one of the non-visiting analysts visit firm $i$ in the subsequent week $t+1$, and zero otherwise.

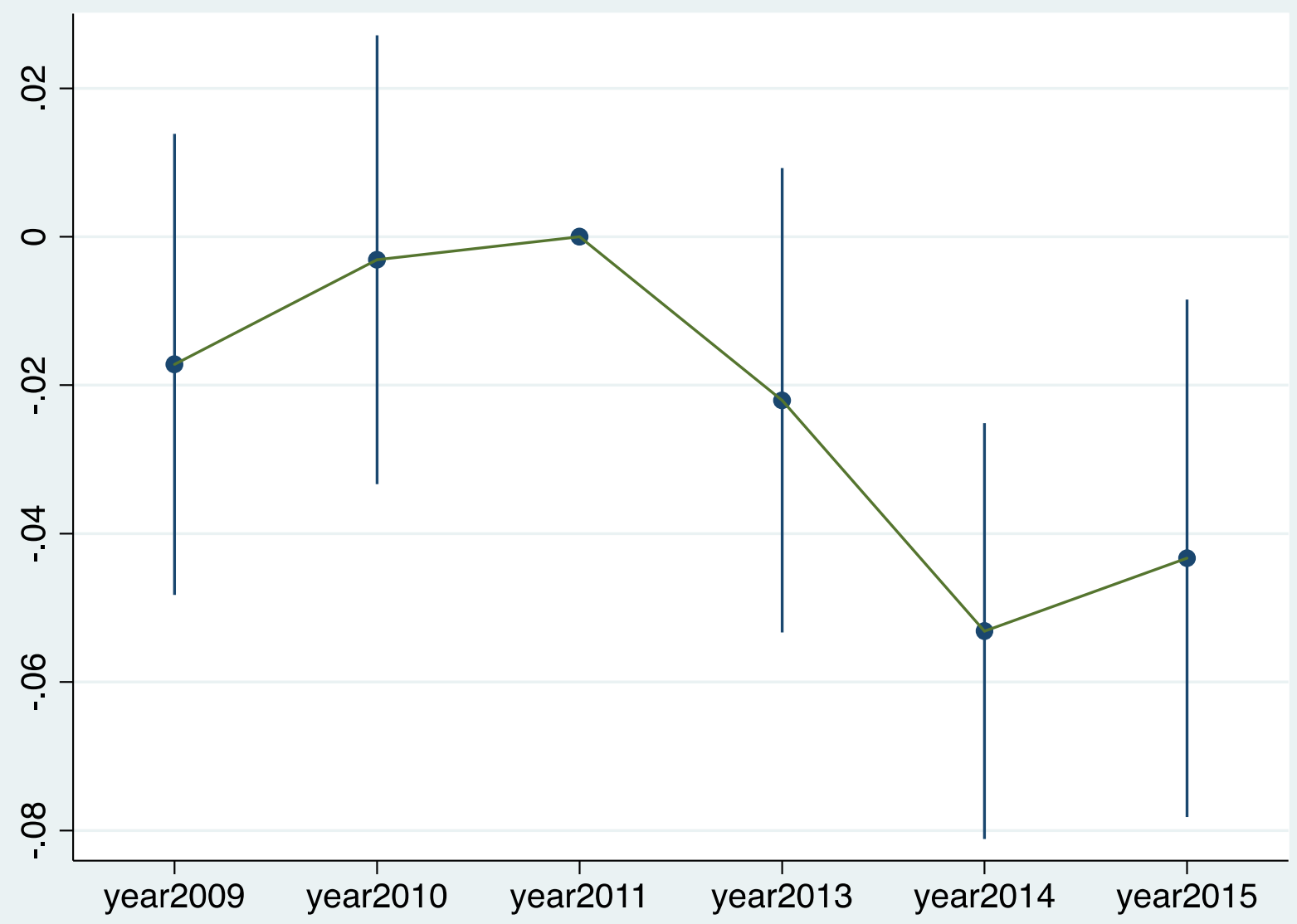




\section{Table 1 Descriptive Statistics}

This table reports the descriptive statistics. Panel A reports the time trend for corporate site visits during the sample period. Columns (1) - (6) report for each year the total number of visits, total number of visiting weeks, average number of visits per firm, average number of visits per broker, average number visiting weeks per firm, average number of visiting weeks per broker, respectively. Columns (7) and (8) report for each year the average number of visits per week and average number of visiting brokers per visit for visited firm-weeks, respectively. Panel B reports summary statistics for all the variables. We exclude observations within four weeks prior to periodic reporting dates. We retain firms with observations available in both pre- and post-periods. All the variables are defined in Appendix 2. All the continuous variables are winsorized at the 1\% and $99 \%$ levels.

Panel A. Time trend of corporate site visits

\begin{tabular}{lcccccccc}
\hline & $(1)$ & $(2)$ & $(3)$ & $(4)$ & $(5)$ & $(6)$ & $(7)$ & $(8)$ \\
\hline Year & \# Visits & $\begin{array}{c}\text { \# Visiting } \\
\text { weeks }\end{array}$ & $\begin{array}{c}\text { \# Visits } \\
\text { per firm }\end{array}$ & $\begin{array}{c}\text { \# Visits } \\
\text { per } \\
\text { broker }\end{array}$ & $\begin{array}{c}\text { \# Visiting } \\
\text { weeks per } \\
\text { firm }\end{array}$ & $\begin{array}{c}\text { \# Visiting } \\
\text { weeks per } \\
\text { broker }\end{array}$ & $\begin{array}{c}\text { \# Visits } \\
\text { per week }\end{array}$ & $\begin{array}{c}\text { \# Brokers } \\
\text { per visit }\end{array}$ \\
\hline 2009 & 1,825 & 45 & 3.337 & 15.716 & 2.389 & 8.506 & 1.122 & 1.240 \\
2010 & 2,607 & 44 & 4.804 & 18.704 & 2.743 & 8.819 & 1.148 & 1.390 \\
2011 & 3,256 & 42 & 5.155 & 26.772 & 3.424 & 10.862 & 1.147 & 1.431 \\
2013 & 2,003 & 43 & 2.974 & 27.464 & 2.141 & 11.251 & 1.131 & 1.786 \\
2014 & 2,403 & 53 & 3.259 & 34.071 & 2.619 & 13.647 & 1.105 & 1.950 \\
2015 & 1,853 & 52 & 2.747 & 25.885 & 2.009 & 12.045 & 1.110 & 1.930 \\
\hline
\end{tabular}

Panel B. Summary statistics

\begin{tabular}{lccccc}
\hline Variables & Mean & Max & Min & P50 & STDEV \\
\hline DvisitF1 & 0.072 & 1.000 & 0.000 & 0.000 & 0.259 \\
DvisitF2 & 0.129 & 1.000 & 0.000 & 0.000 & 0.335 \\
DvisitF3 & 0.177 & 1.000 & 0.000 & 0.000 & 0.382 \\
DvisitF4 & 0.218 & 1.000 & 0.000 & 0.000 & 0.413 \\
Dvisit & 0.073 & 1.000 & 0.000 & 0.000 & 0.260 \\
Post & 0.584 & 1.000 & 0.000 & 1.000 & 0.493 \\
ROA & 0.038 & 0.212 & -0.185 & 0.035 & 0.057 \\
Leverage & 0.456 & 1.010 & 0.040 & 0.451 & 0.225 \\
Size & 21.780 & 25.210 & 19.050 & 21.660 & 1.211 \\
Analyst & 1.520 & 3.738 & 0.000 & 1.609 & 1.191 \\
MB & 3.708 & 20.800 & -0.368 & 2.819 & 3.117 \\
TV & 5.242 & 18.210 & 0.629 & 4.330 & 3.595 \\
Return & 0.010 & 0.340 & -0.240 & 0.001 & 0.102 \\
STD & 0.023 & 0.074 & 0.000 & 0.020 & 0.014 \\
SOE & 0.458 & 1.000 & 0.000 & 0.000 & 0.498 \\
Topl & 0.350 & 0.750 & 0.091 & 0.322 & 0.153 \\
\hline
\end{tabular}




\section{Table 2 Attention Allocated to Visited Firms}

Table 2 reports the results from estimating the equation: Attention $_{i, t}=\alpha+\beta_{1}$ Dvisit $_{i, t}+\beta_{2}$ Post $_{t, t}+\beta_{3}$ Dvisit $_{i, t} \times$ Post $_{t}+\beta_{4}$ Other Controls $+\varepsilon_{i, j, t}$ The dependent variable is the Attention ${ }_{i, t}$ measures examined. For a visited firm in week $t$, we measure Attention $_{i, t}$ as an indicator variable that equals one if at least one non-visiting analyst visits the firm during subsequent weeks. For a non-visited firm $i$, we measure Attention $n_{i, t}$ as an indicator variable that equals one if at least one analyst visits the firm during subsequent weeks. We use DvisitF $1_{i, t}\left(\right.$ DvisitF $_{i, t}$, DvisitF $3_{i, t}$, DvisitF $\left.4_{i, t}\right)$ to indicate the attention allocated to firm $i$ in the subsequent week (two weeks, three weeks, four weeks). All the variables are defined in Appendix 2. All the specifications include firm fixed effects and year-week fixed effects. $t$-statistics, based on robust standard errors clustered by firm and year-week, are presented below the coefficient estimates.

\begin{tabular}{|c|c|c|c|c|}
\hline VARIABLES & $\begin{array}{c}(1) \\
\text { DvisitF1 }\end{array}$ & $\begin{array}{c}(2) \\
\text { DvisitF2 }\end{array}$ & $\begin{array}{c}\text { (3) } \\
\text { DvisitF3 }\end{array}$ & $\begin{array}{c}(4) \\
\text { DvisitF4 }\end{array}$ \\
\hline Dvisit & $\begin{array}{c}0.090 * * * \\
(12.24)\end{array}$ & $\begin{array}{c}0.132 * * * \\
(14.40)\end{array}$ & $\begin{array}{c}0.150 * * * \\
(14.40)\end{array}$ & $\begin{array}{c}0.153 * * * \\
(13.96)\end{array}$ \\
\hline Dvisit $\times$ Post & $\begin{array}{c}-0.035 * * * \\
(-3.44)\end{array}$ & $\begin{array}{c}-0.055 * * * \\
(-4.31)\end{array}$ & $\begin{array}{c}-0.066 * * * \\
(-4.58)\end{array}$ & $\begin{array}{c}-0.071 * * * \\
(-4.76)\end{array}$ \\
\hline$R O A$ & $\begin{array}{c}0.111 * * * \\
(4.26)\end{array}$ & $\begin{array}{c}0.190 * * * \\
(4.27)\end{array}$ & $\begin{array}{c}0.252 * * * \\
(4.36)\end{array}$ & $\begin{array}{c}0.297 * * * \\
(4.32)\end{array}$ \\
\hline Leverage & $\begin{array}{l}-0.007 \\
(-0.54)\end{array}$ & $\begin{array}{l}-0.007 \\
(-0.32)\end{array}$ & $\begin{array}{l}-0.004 \\
(-0.16)\end{array}$ & $\begin{array}{l}-0.008 \\
(-0.24)\end{array}$ \\
\hline Size & $\begin{array}{c}0.012 * * * \\
(2.68)\end{array}$ & $\begin{array}{c}0.019 * * \\
(2.57)\end{array}$ & $\begin{array}{c}0.025 * * \\
(2.59)\end{array}$ & $\begin{array}{c}0.030 * * * \\
(2.65)\end{array}$ \\
\hline Analyst & $\begin{array}{l}0.002 \\
(1.00)\end{array}$ & $\begin{array}{l}0.006^{*} \\
(1.78)\end{array}$ & $\begin{array}{c}0.010 * * \\
(2.21)\end{array}$ & $\begin{array}{c}0.014 * * \\
(2.55)\end{array}$ \\
\hline$M B$ & $\begin{array}{c}0.002 * * * \\
(3.12)\end{array}$ & $\begin{array}{c}0.003 * * * \\
(3.04)\end{array}$ & $\begin{array}{c}0.003 * * * \\
(2.99)\end{array}$ & $\begin{array}{c}0.004 * * * \\
(2.97)\end{array}$ \\
\hline$T V$ & $\begin{array}{c}-0.001 * * * \\
(-2.70)\end{array}$ & $\begin{array}{c}-0.002 * * \\
(-2.58)\end{array}$ & $\begin{array}{c}-0.002 * * \\
(-2.28)\end{array}$ & $\begin{array}{c}-0.002 * * \\
(-2.02)\end{array}$ \\
\hline Return & $\begin{array}{l}0.071 * * * \\
(8.56)\end{array}$ & $\begin{array}{l}0.104 * * * \\
\quad(8.23)\end{array}$ & $\begin{array}{c}0.129 * * * \\
(8.29)\end{array}$ & $\begin{array}{c}0.140 * * * \\
(8.21)\end{array}$ \\
\hline STD & $\begin{array}{c}0.518 * * * \\
(6.66)\end{array}$ & $\begin{array}{c}0.776 * * * \\
(7.10)\end{array}$ & $\begin{array}{c}0.905 * * * \\
(7.43)\end{array}$ & $\begin{array}{c}0.946 * * * \\
(7.01)\end{array}$ \\
\hline$S O E$ & $\begin{array}{l}-0.009 \\
(-1.07)\end{array}$ & $\begin{array}{l}-0.016 \\
(-1.12)\end{array}$ & $\begin{array}{l}-0.018 \\
(-0.92)\end{array}$ & $\begin{array}{l}-0.021 \\
(-0.90)\end{array}$ \\
\hline Topl & $\begin{array}{l}-0.035 \\
(-0.95)\end{array}$ & $\begin{array}{l}-0.042 \\
(-0.73)\end{array}$ & $\begin{array}{l}-0.039 \\
(-0.55)\end{array}$ & $\begin{array}{l}-0.038 \\
(-0.46)\end{array}$ \\
\hline Constant & $\begin{array}{c}-0.191 * * \\
(-1.97)\end{array}$ & $\begin{array}{c}-0.300 * \\
(-1.85)\end{array}$ & $\begin{array}{c}-0.390^{*} \\
(-1.88)\end{array}$ & $\begin{array}{c}-0.475^{*} \\
(-1.92)\end{array}$ \\
\hline $\begin{array}{l}\text { Firm FE } \\
\text { Year-week FE }\end{array}$ & $\begin{array}{l}\text { Yes } \\
\text { Yes }\end{array}$ & $\begin{array}{l}\text { Yes } \\
\text { Yes }\end{array}$ & $\begin{array}{l}\text { Yes } \\
\text { Yes }\end{array}$ & $\begin{array}{l}\text { Yes } \\
\text { Yes }\end{array}$ \\
\hline $\begin{array}{l}\text { Observations } \\
\text { Adjusted } \mathrm{R}^{2}\end{array}$ & $\begin{array}{c}169,496 \\
0.089\end{array}$ & $\begin{array}{c}169,496 \\
0.145\end{array}$ & $\begin{array}{c}169,496 \\
0.184\end{array}$ & $\begin{array}{c}169,496 \\
0.215\end{array}$ \\
\hline
\end{tabular}


Table 3 Cross-sectional Analyses

This table reports the results of cross-sectional analyses. Panel A reports the results from estimating the equation: Attention $i, t=$ $\alpha+\beta_{1}$ Dvisit_Recent $_{i, t}+\beta_{2}$ Dvisit_NonRecent $_{i, t}+\beta_{3}$ Post $_{i, t}+\beta_{4}$ Dvisit_Recent $_{i, t} \times$ Post $_{i, t}+\beta_{5}$ Dvisit_NonRecent $_{i, t} \times$

Post $_{i, t}+\varepsilon_{i, t}$. Also reported are the F-statistics and p-values of testing the differences between the coefficients on Dvisit_Recent $\times$ Post and Dvisit_NonRecent $\times$ Post. Panel B reports the results from estimating the equation: Attention ${ }_{i, t}=\alpha+$ $\beta_{1}$ Dvisit_Follow $_{i, t}+\beta_{2}$ Dvisit_NonFollow $_{i, t}+\beta_{3}$ Post $_{i, t}+\beta_{4}$ Dvisit_Follow $_{i, t} \times$ Post $_{i, t}+\beta_{5}$ Dvisit_NonFollow $_{i, t} \times$

Post $_{i, t}+\varepsilon_{i, t}$. Also reported are the F-statistics and p-values of testing the differences between Dvisit_Follow $\times$ Post and Dvisit_NonFollow $\times$ Post. Panel C reports the results from estimating the equation: Attention $i, t=\alpha+\beta_{1} D_{\text {Dvisit_STAR }}, t+$ $\beta_{2}$ Dvisit_NonST AR $_{i, t}+\beta_{3}$ Post $_{i, t}+\beta_{4}$ Dvisit_ST AR $_{i, t} \times$ Post $_{i, t}+\beta_{5}$ Dvisit_NonST AR $_{i, t} \times$ Post $_{i, t}+\varepsilon_{i, t}$. Also reported are the F-statistics and p-values of testing the differences between Dvisit_STAR $\times$ Post and Dvisit_NonSTAR $\times$ Post. The dependent variable is the Attention $i, t$ measures examined. Columns (1)-(4) of Panels A and B report the tendency to visit firms by non-visiting analysts one week (DvisitF1), two weeks (DvisitF2), three weeks (DvisitF3), and four weeks (DvisitF4) subsequent to week $t$ for firm $i$, respectively. All the variables are defined in Appendix 2. All the specifications include firm fixed effects and year-week fixed effects. $t$-statistics, based on robust standard errors clustered by firm and year-week, are presented below the coefficient estimates.

Panel A Cross-sectional analyses based on the recent visiting history of visiting analysts

\begin{tabular}{|c|c|c|c|c|}
\hline VARIABLES & $\begin{array}{c}(1) \\
\text { DvisitF1 }\end{array}$ & $\begin{array}{c}(2) \\
\text { DvisitF2 }\end{array}$ & $\begin{array}{c}\text { (3) } \\
\text { DvisitF3 }\end{array}$ & $\begin{array}{c}(4) \\
\text { DvisitF4 }\end{array}$ \\
\hline Dvisit_Recent & $\begin{array}{c}0.104 * * * \\
(8.88)\end{array}$ & $\begin{array}{c}0.146 * * * \\
(10.50)\end{array}$ & $\begin{array}{c}0.163 * * * \\
(10.77)\end{array}$ & $\begin{array}{c}0.163 * * * \\
(10.14)\end{array}$ \\
\hline Dvisit_NonRecent & $\begin{array}{c}0.081 * * * \\
(10.80)\end{array}$ & $\begin{array}{c}0.122 * * * \\
(13.49)\end{array}$ & $\begin{array}{c}0.142 * * * \\
(14.47)\end{array}$ & $\begin{array}{c}0.146^{* * * *} \\
(14.56)\end{array}$ \\
\hline Dvisit_Recent $\times$ Post & $\begin{array}{c}-0.046 * * * \\
(-3.10)\end{array}$ & $\begin{array}{c}-0.074 * * * \\
(-4.16)\end{array}$ & $\begin{array}{c}-0.086 * * * \\
(-4.41)\end{array}$ & $\begin{array}{c}-0.091 * * * \\
(-4.40)\end{array}$ \\
\hline Dvisit_NonRecent $\times$ Post & $\begin{array}{c}-0.028 * * \\
(-2.54)\end{array}$ & $\begin{array}{c}-0.039 * * * \\
(-2.85)\end{array}$ & $\begin{array}{c}-0.048 * * * \\
(-3.23)\end{array}$ & $\begin{array}{c}-0.054 * * * \\
(-3.54)\end{array}$ \\
\hline Controls & Yes & Yes & Yes & Yes \\
\hline Firm FE & Yes & Yes & Yes & Yes \\
\hline Year FE & Yes & Yes & Yes & Yes \\
\hline F-test & -0.018 & $-0.035 *$ & $-0.039 * *$ & $-0.037 * *$ \\
\hline P-value & $(0.260)$ & $(0.058)$ & $(0.041)$ & $(0.018)$ \\
\hline Observations & 169,496 & 169,496 & 169,496 & 169,496 \\
\hline Adjusted $\mathrm{R}^{2}$ & 0.089 & 0.145 & 0.184 & 0.215 \\
\hline
\end{tabular}


Panel B Cross-sectional analyses based on the recent forecasting history of visiting analysts

\begin{tabular}{|c|c|c|c|c|}
\hline & (1) & (2) & (3) & (4) \\
\hline VARIABLES & DvisitF 1 & DvsitF2 & DvisitF3 & DvisitF4 \\
\hline \multirow[t]{2}{*}{ Dvisit_Follow } & $0.099 * * *$ & $0.143^{* * *}$ & $0.163 * * *$ & $0.161 * * *$ \\
\hline & $(8.46)$ & $(10.43)$ & $(10.95)$ & $(10.01)$ \\
\hline \multirow[t]{2}{*}{ Dvisit_NonFollow } & $0.085 * * *$ & $0.125 * * *$ & $0.143 * * *$ & $0.148 * * *$ \\
\hline & $(11.73)$ & $(13.43)$ & $(13.61)$ & $(14.01)$ \\
\hline \multirow[t]{2}{*}{ Dvisit_Follow $\times$ Post } & $-0.062 * * *$ & $-0.096 * * *$ & $-0.117 * * *$ & $-0.123 * * *$ \\
\hline & $(-4.22)$ & $(-5.40)$ & $(-5.88)$ & $(-5.90)$ \\
\hline \multirow[t]{2}{*}{ Dvisit_NonFollow $\times$ Post } & -0.016 & $-0.024 *$ & $-0.027 *$ & $-0.032 * *$ \\
\hline & $(-1.37)$ & $(-1.71)$ & $(-1.80)$ & $(-2.07)$ \\
\hline Controls & Yes & Yes & Yes & Yes \\
\hline Firm FE & Yes & Yes & Yes & Yes \\
\hline Year FE & Yes & Yes & Yes & Yes \\
\hline F-test & $-0.046 * * *$ & $-0.073 * * *$ & $-0.090 * * *$ & $-0.091 * * *$ \\
\hline P-value & $(0.004)$ & $(0.000)$ & $(0.000)$ & $(0.000)$ \\
\hline Observations & 169,496 & 169,496 & 169,496 & 169,496 \\
\hline Adjusted $\mathrm{R}^{2}$ & 0.089 & 0.145 & 0.185 & 0.215 \\
\hline
\end{tabular}

Panel C Cross-sectional analyses based on being a star analyst

\begin{tabular}{|c|c|c|c|c|}
\hline & (1) & (2) & (3) & (4) \\
\hline VARIABLES & DvisitF1 & DvisitF2 & DvisitF3 & DvisitF4 \\
\hline \multirow[t]{2}{*}{ Dvisit_STAR } & $0.105 * * *$ & $0.143 * * *$ & $0.150 * * *$ & $0.152 * * *$ \\
\hline & $(6.58)$ & $(7.56)$ & $(8.01)$ & $(7.36)$ \\
\hline \multirow[t]{2}{*}{ Dvisit_NonSTAR } & $0.087 * * *$ & $0.130 * * *$ & $0.150 * * *$ & $0.153 * * *$ \\
\hline & $(12.13)$ & $(14.65)$ & $(15.02)$ & $(14.87)$ \\
\hline \multirow[t]{2}{*}{ Dvisit_STAR $\times$ Post } & $\mathbf{- 0 . 0 7 8} * * *$ & $-0.110 * * *$ & $-0.117 * * *$ & $-0.128 * * *$ \\
\hline & $(-3.93)$ & $(-4.51)$ & $(-4.58)$ & $(-4.75)$ \\
\hline \multirow{2}{*}{ Dvisit_NonSTAR $\times$ Post } & $-0.023 * *$ & $-0.037 * * *$ & $-0.048 * * *$ & $-0.052 * * *$ \\
\hline & $(-2.12)$ & $(-2.88)$ & $(-3.42)$ & $(-3.62)$ \\
\hline Controls & Yes & Yes & Yes & Yes \\
\hline Firm FE & Yes & Yes & Yes & Yes \\
\hline Year FE & Yes & Yes & Yes & Yes \\
\hline F-test & $-\mathbf{0 . 0 5 5} * * *$ & $-0.073 * * *$ & $-0.069 * * *$ & $-\mathbf{0 . 0 7 7} * * *$ \\
\hline P-value & $(0.006)$ & $(0.003)$ & $(0.003)$ & $(0.001)$ \\
\hline Observations & 169,496 & 169,496 & 169,496 & 169,496 \\
\hline Adjusted $\mathrm{R}^{2}$ & 0.089 & 0.145 & 0.185 & 0.215 \\
\hline
\end{tabular}




\section{Table 4 Attention Allocated to Non-visited Firms}

Table 4 reports the results of examining attention allocated to non-visited firms from estimating the equation: Attention_nonvisit $=\alpha+\beta_{1}$ Peervisit ${ }_{t, t}+\beta_{2}$ Post $_{t, t}+\beta_{3}$ Peervisit ${ }_{l, t} \times$ Post $_{t}+\beta_{4}$ Other Controls $+\varepsilon_{i, t,}$ The dependent variable is the Attention_nonvisitit, measures examined. Peervisit $t_{i . t}$ captures the proportion of peer firms within firm $i$ 's industry that are visited during week $t$. DvisitF1 $1_{i, t}\left(\right.$ DvisitF2 $_{i, t}$, DvisitF3 $_{i, t}$, DvisitF4 $\left.4_{i, t}\right)$ is an indicator variable that equals one if at least one of the nonvisiting analysts (i.e., analysts who do not visit any peer firms in week $t$ ) visit firm $i$ in the subsequent week (two weeks, three weeks, four weeks), and zero if none of these analysts visit firm $i$ in the subsequent week (two weeks, three weeks, four weeks). All the variables are defined in the appendix. All the specifications include firm fixed effects and year-week fixed effects. $t$-statistics, based on robust standard errors clustered by firm and year-week, are presented below the coefficient estimates.

\begin{tabular}{|c|c|c|c|c|}
\hline VARIABLES & $\begin{array}{c}(1) \\
\text { DVisitF1 }\end{array}$ & $\begin{array}{c}(2) \\
\text { DvisitF2 }\end{array}$ & $\begin{array}{c}(3) \\
\text { DvisitF3 }\end{array}$ & $\begin{array}{c}(4) \\
\text { DvisitF4 }\end{array}$ \\
\hline Peervisit & $\begin{array}{l}0.018 \\
(1.03)\end{array}$ & $\begin{array}{l}0.034 \\
(1.28)\end{array}$ & $\begin{array}{c}0.064 * * \\
(1.97)\end{array}$ & $\begin{array}{l}0.043 \\
(1.15)\end{array}$ \\
\hline Peervisit $\times$ Post & $\begin{array}{c}0.063 * * \\
(2.38)\end{array}$ & $\begin{array}{c}0.103 * * * \\
(2.67)\end{array}$ & $\begin{array}{c}0.094 * * \\
(2.02)\end{array}$ & $\begin{array}{c}0.116 * * \\
(2.28)\end{array}$ \\
\hline$R O A$ & $\begin{array}{c}0.103 * * * \\
(4.25)\end{array}$ & $\begin{array}{c}0.186^{* * * *} \\
(4.36)\end{array}$ & $\begin{array}{c}0.237 * * * \\
(4.25)\end{array}$ & $\begin{array}{c}0.281 \text { *** } \\
(4.17)\end{array}$ \\
\hline Leverage & $\begin{array}{l}-0.003 \\
(-0.25)\end{array}$ & $\begin{array}{l}-0.002 \\
(-0.08)\end{array}$ & $\begin{array}{l}-0.004 \\
(-0.13)\end{array}$ & $\begin{array}{l}-0.007 \\
(-0.22)\end{array}$ \\
\hline Size & $\begin{array}{c}0.011 * * \\
(2.54)\end{array}$ & $\begin{array}{c}0.017 * * \\
(2.43)\end{array}$ & $\begin{array}{c}0.024 * * \\
(2.49)\end{array}$ & $\begin{array}{c}0.029 * * \\
(2.55)\end{array}$ \\
\hline Analyst & $\begin{array}{l}0.004 * \\
(1.82)\end{array}$ & $\begin{array}{c}0.008 * * \\
(2.39)\end{array}$ & $\begin{array}{c}0.012 * * * \\
(2.70)\end{array}$ & $\begin{array}{c}0.015^{* * *} \\
(2.81)\end{array}$ \\
\hline$M B$ & $\begin{array}{c}0.002 * * * \\
(3.20)\end{array}$ & $\begin{array}{c}0.002 * * * \\
(3.03)\end{array}$ & $\begin{array}{c}0.003 * * * \\
(2.94)\end{array}$ & $\begin{array}{c}0.004 * * * \\
(2.96)\end{array}$ \\
\hline$T V$ & $\begin{array}{c}-0.001 * * * \\
(-2.64)\end{array}$ & $\begin{array}{c}-0.002 * * \\
(-2.48)\end{array}$ & $\begin{array}{c}-0.002 * * \\
(-2.18)\end{array}$ & $\begin{array}{c}-0.002 * \\
(-1.96)\end{array}$ \\
\hline Return & $\begin{array}{c}0.066^{* * * *} \\
(8.34)\end{array}$ & $\begin{array}{c}0.101 * * * \\
(8.08)\end{array}$ & $\begin{array}{c}0.125 * * * \\
(7.94)\end{array}$ & $\begin{array}{c}0.138 * * * \\
(8.07)\end{array}$ \\
\hline$S T D$ & $\begin{array}{c}0.461 * * * \\
\quad(6.09)\end{array}$ & $\begin{array}{c}0.697 * * * \\
(6.57)\end{array}$ & $\begin{array}{c}0.826 * * * \\
(6.83)\end{array}$ & $\begin{array}{c}0.895 * * * \\
(6.52)\end{array}$ \\
\hline$S O E$ & $\begin{array}{l}-0.009 \\
(-1.12)\end{array}$ & $\begin{array}{l}-0.015 \\
(-1.04)\end{array}$ & $\begin{array}{l}-0.015 \\
(-0.78)\end{array}$ & $\begin{array}{l}-0.020 \\
(-0.87)\end{array}$ \\
\hline Topl & $\begin{array}{l}-0.015 \\
(-0.49)\end{array}$ & $\begin{array}{l}-0.018 \\
(-0.36)\end{array}$ & $\begin{array}{l}-0.015 \\
(-0.23)\end{array}$ & $\begin{array}{l}-0.012 \\
(-0.16)\end{array}$ \\
\hline Constant & $\begin{array}{c}-0.182^{*} \\
(-1.97)\end{array}$ & $\begin{array}{c}-0.294 * \\
(-1.86)\end{array}$ & $\begin{array}{l}-0.401 * \\
(-1.92)\end{array}$ & $\begin{array}{c}-0.490 * \\
(-1.94)\end{array}$ \\
\hline $\begin{array}{l}\text { Firm FE } \\
\text { Year-week FE }\end{array}$ & $\begin{array}{l}\text { Yes } \\
\text { Yes }\end{array}$ & $\begin{array}{l}\text { Yes } \\
\text { Yes }\end{array}$ & $\begin{array}{l}\text { Yes } \\
\text { Yes }\end{array}$ & $\begin{array}{l}\text { Yes } \\
\text { Yes }\end{array}$ \\
\hline $\begin{array}{l}\text { Observations } \\
\text { Adjusted } \mathrm{R}^{2}\end{array}$ & $\begin{array}{c}156,044 \\
0.070\end{array}$ & $\begin{array}{c}156,044 \\
0.122\end{array}$ & $\begin{array}{c}156,044 \\
0.162\end{array}$ & $\begin{array}{c}156,044 \\
0.194\end{array}$ \\
\hline
\end{tabular}




\section{Table 5 Effects on Visited Firms' Informational Efficiency}

Table 5 reports the results of examining the effects on visited firms' informational efficiency by estimating the equation: SYNCH $_{i, t}=\alpha+\beta_{1}$ Dvisit $_{i, t}+\beta_{2}$ Post $_{t}+\beta_{3}$ Dvisit $_{i, t} \times$ Post $_{t}+\beta_{4}$ Other Controls $+\varepsilon_{i, t}$. Columns (1)-(3) report the synchronicity two weeks (SYNCH2), three weeks (SYNCH3), and four weeks (SYNCH4) subsequent to week $t$ for firm $i$, respectively. All the variables are defined in Appendix 2. All the specifications include firm fixed effects and year-week fixed effects. $t$-statistics, based on robust standard errors clustered by firm and year-week, are presented below the coefficient estimates.

\begin{tabular}{|c|c|c|c|}
\hline VARIABLES & $\begin{array}{c}(1) \\
\text { SYNCH2 }\end{array}$ & $\begin{array}{c}(2) \\
\text { SYNCH3 }\end{array}$ & $\begin{array}{c}\text { (3) } \\
\text { SYNCH4 }\end{array}$ \\
\hline Dvisit & $\begin{array}{c}-0.062 * * * \\
(-3.02)\end{array}$ & $\begin{array}{c}-0.064 * * * \\
(-3.30)\end{array}$ & $\begin{array}{c}-0.058 * * * \\
(-3.22)\end{array}$ \\
\hline Dvisit $\times$ Post & $\begin{array}{c}\text { 0.056* } \\
(1.88)\end{array}$ & $\begin{array}{l}0.028 \\
(0.99)\end{array}$ & $\begin{array}{l}\text { 0.047* } \\
(1.80)\end{array}$ \\
\hline$R O A$ & $\begin{array}{c}0.791 * * * \\
(4.57)\end{array}$ & $\begin{array}{c}0.882 * * * \\
(4.79)\end{array}$ & $\begin{array}{c}0.970 * * * \\
(5.07)\end{array}$ \\
\hline Leverage & $\begin{array}{c}-0.227 * * * \\
(-2.83)\end{array}$ & $\begin{array}{c}-0.247 * * * \\
(-2.94)\end{array}$ & $\begin{array}{c}-0.228 * * * \\
(-2.60)\end{array}$ \\
\hline Size & $\begin{array}{c}0.174 * * * \\
(7.35)\end{array}$ & $\begin{array}{c}0.190 * * * \\
(7.38)\end{array}$ & $\begin{array}{c}0.203 * * * \\
(7.59)\end{array}$ \\
\hline Analyst & $\begin{array}{c}0.034 * * * \\
(2.82)\end{array}$ & $\begin{array}{c}0.043 * * * \\
(3.49)\end{array}$ & $\begin{array}{c}0.048 * * * \\
(3.75)\end{array}$ \\
\hline$M B$ & $\begin{array}{c}-0.010 * * * \\
(-2.89)\end{array}$ & $\begin{array}{c}-0.009 * * \\
(-2.39)\end{array}$ & $\begin{array}{c}-0.010 * * \\
(-2.33)\end{array}$ \\
\hline$T V$ & $\begin{array}{c}0.009 * * * \\
(3.07)\end{array}$ & $\begin{array}{c}0.010 * * * \\
(3.00)\end{array}$ & $\begin{array}{c}0.011 * * * \\
(3.40)\end{array}$ \\
\hline Return & $\begin{array}{c}-1.016 * * * \\
(-13.78)\end{array}$ & $\begin{array}{c}-0.975 * * * \\
(-13.78)\end{array}$ & $\begin{array}{c}-0.915 * * * \\
(-13.60)\end{array}$ \\
\hline$S T D$ & $\begin{array}{c}-3.995 * * * \\
(-3.41)\end{array}$ & $\begin{array}{c}-4.136 * * * \\
(-3.98)\end{array}$ & $\begin{array}{c}-3.782 * * * \\
(-4.18)\end{array}$ \\
\hline$S O E$ & $\begin{array}{l}-0.036 \\
(-0.60)\end{array}$ & $\begin{array}{l}-0.022 \\
(-0.32)\end{array}$ & $\begin{array}{l}-0.039 \\
(-0.52)\end{array}$ \\
\hline Topl & $\begin{array}{c}-0.352 * * \\
(-2.25)\end{array}$ & $\begin{array}{c}-0.372 * * \\
(-2.28)\end{array}$ & $\begin{array}{c}-0.456 * * * \\
(-2.69)\end{array}$ \\
\hline Constant & $\begin{array}{c}-3.575 * * * \\
(-7.09)\end{array}$ & $\begin{array}{c}-4.066 * * * \\
(-7.47)\end{array}$ & $\begin{array}{c}-4.419 * * * \\
(-7.80)\end{array}$ \\
\hline Firm FE & Yes & Yes & Yes \\
\hline Year-week FE & Yes & Yes & Yes \\
\hline $\begin{array}{l}\text { Observations } \\
\text { Adjusted } \mathrm{R}^{2}\end{array}$ & $\begin{array}{c}147,791 \\
0.254\end{array}$ & $\begin{array}{c}153,699 \\
0.305\end{array}$ & $\begin{array}{c}157,357 \\
0.340\end{array}$ \\
\hline
\end{tabular}




\section{Table 6 Effects on Non-visiting Peer Firms' Informational Environment}

Table 6 reports the results of examining the effects on non-visited firms' information environment by estimating the equation: SYNCH $_{i, t}=\alpha+\beta_{1}$ Peervisit $_{i, t}+\beta_{2}$ Post $_{t}+\beta_{3}$ Peervisit $_{i, t} \times$ Post $_{t}+\beta_{4}$ Other Controls $+\varepsilon_{i, t}$. Peervisit ${ }_{i . t}$ captures the proportion of peer firms within firm $i$ 's industry that are visited during week $t$. Columns (1)-(3) report the synchronicity two weeks (SYNCH2), three weeks (SYNCH3), and four weeks (SYNCH4) subsequent to week $t$ for non-visited firm $i$, respectively. All the variables are defined in the appendix. All the specifications include firm fixed effects and year-week fixed effects. $t$-statistics, based on robust standard errors clustered by firm and year-week, are presented below the coefficient estimates.

\begin{tabular}{|c|c|c|c|}
\hline VARIABLES & $\begin{array}{c}(1) \\
\text { SYNCH2 }\end{array}$ & $\begin{array}{c}(2) \\
\text { SYNCH3 }\end{array}$ & $\begin{array}{c}\text { (3) } \\
\text { SYNCH4 }\end{array}$ \\
\hline Peervisit & $\begin{array}{c}0.304 * * * \\
(2.80)\end{array}$ & $\begin{array}{l}0.313 * * * \\
(2.86)\end{array}$ & $\begin{array}{l}0.307 * * * \\
(2.72)\end{array}$ \\
\hline Peervisit $\times$ Post & $\begin{array}{c}-0.239 * \\
(-1.70)\end{array}$ & $\begin{array}{c}-0.299 * * \\
(-2.13)\end{array}$ & $\begin{array}{c}-0.357 * * \\
(-2.42)\end{array}$ \\
\hline$R O A$ & $\begin{array}{c}0.794 * * * \\
(4.58)\end{array}$ & $\begin{array}{c}0.865 * * * \\
(4.67)\end{array}$ & $\begin{array}{c}0.966^{* * * *} \\
(5.04)\end{array}$ \\
\hline Leverage & $\begin{array}{c}-0.238 * * * \\
(-2.89)\end{array}$ & $\begin{array}{c}-0.252 * * * \\
(-2.93)\end{array}$ & $\begin{array}{c}-0.233^{* *} \\
(-2.58)\end{array}$ \\
\hline Size & $\begin{array}{c}0.179 * * * \\
(7.42)\end{array}$ & $\begin{array}{c}0.193 * * * \\
(7.35)\end{array}$ & $\begin{array}{c}0.205^{* * * *} \\
(7.51)\end{array}$ \\
\hline Analyst & $\begin{array}{c}0.031 * * * \\
(2.62)\end{array}$ & $\begin{array}{c}0.043 * * * \\
(3.41)\end{array}$ & $\begin{array}{c}0.047 * * * \\
(3.58)\end{array}$ \\
\hline$M B$ & $\begin{array}{c}-0.010 * * * \\
(-2.83)\end{array}$ & $\begin{array}{c}-0.010 * * \\
(-2.41)\end{array}$ & $\begin{array}{c}-0.010^{* *} \\
(-2.32)\end{array}$ \\
\hline$T V$ & $\begin{array}{c}0.009 * * * \\
(2.92)\end{array}$ & $\begin{array}{c}0.010 * * * \\
(3.00)\end{array}$ & $\begin{array}{c}0.011 * * * \\
(3.36)\end{array}$ \\
\hline Return & $\begin{array}{c}-1.003 * * * \\
(-13.58)\end{array}$ & $\begin{array}{c}-0.961 * * * \\
(-13.48)\end{array}$ & $\begin{array}{c}-0.896 * * * \\
(-13.25)\end{array}$ \\
\hline$S T D$ & $\begin{array}{c}-4.203 * * * \\
(-3.53)\end{array}$ & $\begin{array}{c}-4.253 * * * \\
(-4.04)\end{array}$ & $\begin{array}{c}-3.840 * * * \\
(-4.22)\end{array}$ \\
\hline$S O E$ & $\begin{array}{l}-0.061 \\
(-1.02)\end{array}$ & $\begin{array}{l}-0.048 \\
(-0.69)\end{array}$ & $\begin{array}{l}-0.058 \\
(-0.78)\end{array}$ \\
\hline Top1 & $\begin{array}{c}-0.383 * * \\
(-2.50)\end{array}$ & $\begin{array}{c}-0.414 * * \\
(-2.59)\end{array}$ & $\begin{array}{c}-0.500 * * * \\
(-3.02)\end{array}$ \\
\hline Constant & $\begin{array}{c}-3.645 * * * \\
(-7.08)\end{array}$ & $\begin{array}{c}-4.113 * * * \\
(-7.35)\end{array}$ & $\begin{array}{c}-4.448 * * * \\
(-7.63)\end{array}$ \\
\hline $\begin{array}{l}\text { Firm FE } \\
\text { Year-week FE }\end{array}$ & $\begin{array}{l}\text { Yes } \\
\text { Yes }\end{array}$ & $\begin{array}{l}\text { Yes } \\
\text { Yes }\end{array}$ & $\begin{array}{l}\text { Yes } \\
\text { Yes }\end{array}$ \\
\hline $\begin{array}{l}\text { Observations } \\
\text { Adjusted R-squared }\end{array}$ & $\begin{array}{c}136,062 \\
0.253 \\
\end{array}$ & $\begin{array}{c}141,525 \\
0.303 \\
\end{array}$ & $\begin{array}{c}144,927 \\
0.339 \\
\end{array}$ \\
\hline
\end{tabular}




\section{Table 7 Alternative Explanation - Firms Combining Visits}

Table 7 reports the results of our attempt to mitigate the concern of the alternative explanation. We re-estimate equation (1) based on whether (1) a visited firm-week involves multiple analysts (Panel A) and (2) a board secretary is busy or not (Panel B). A busy secretary is defined as one with the number of board meetings above the sample median during the pre-period. We use $D v i s i t F 1_{i, t}$ (DvisitF2 ${ }_{i, t}$, DvisitF $_{i, t}, D v i s i t F 4_{i, t}$ ) to indicate the attention paid to firm $i$ in the subsequent week (two weeks, three weeks, four weeks). Also reported are the F-statistics and p-values of testing the differences between Dvisit_Multiple $\times$ Post and Dvisit_Single $\times$ Post, as well as the $\chi^{2}$-statistics and $\mathrm{p}$-values of testing the differences between firms with busy secretaries and other firms. All the variables are defined in the appendix. All the specifications include firm fixed effects and year-week fixed effects. $t$ statistics based on robust standard errors clustered by firm and year-week are presented below the coefficient estimates.

Panel A Cross-sectional analysis based on number of visiting analysts

\begin{tabular}{|c|c|c|c|c|}
\hline & (1) & (2) & (3) & (4) \\
\hline VARIABLES & DvisitF1 & DvisitF2 & DvisitF3 & DvisitF4 \\
\hline \multirow[t]{2}{*}{ Dvisit_Multiple } & $0.081 * * *$ & $0.121 * * *$ & $0.140 * * *$ & $0.146^{* * *}$ \\
\hline & $(10.87)$ & $(12.66)$ & $(12.75)$ & $(13.13)$ \\
\hline \multirow[t]{2}{*}{ Dvisit_Single } & $0.106 * * *$ & $0.151 * * *$ & $0.168 * * *$ & $0.165 * * *$ \\
\hline & $(9.25)$ & $(11.56)$ & $(12.09)$ & $(10.73)$ \\
\hline \multirow[t]{2}{*}{ Dvisit_Multiple $\times$ Post } & $-0.048 * * *$ & $-0.075 * * *$ & $-0.089 * * *$ & $-0.090 * * *$ \\
\hline & $(-3.32)$ & $(-4.49)$ & $(-4.79)$ & $(-4.54)$ \\
\hline \multirow[t]{2}{*}{ Dvisit_Single $\times$ Post } & $-0.028 * *$ & $-0.042 * * *$ & $-0.050 * * *$ & $-0.057 * * *$ \\
\hline & $(-2.54)$ & $(-3.03)$ & $(-3.24)$ & $(-3.70)$ \\
\hline Controls & Yes & Yes & Yes & Yes \\
\hline Firm FE & Yes & Yes & Yes & Yes \\
\hline Year FE & Yes & Yes & Yes & Yes \\
\hline F-test & -0.020 & $-0.033 * *$ & $-0.039 * *$ & $-0.032 * *$ \\
\hline P-value & $(0.260)$ & $(0.046)$ & $(0.026)$ & $(\mathbf{0 . 0 1 8})$ \\
\hline Observations & 169,496 & 169,496 & 169,496 & 169,496 \\
\hline Adjusted $\mathrm{R}^{2}$ & 0.192 & 0.145 & 0.184 & 0.215 \\
\hline
\end{tabular}

Panel B Cross-sectional analysis based on busy secretary

\begin{tabular}{|c|c|c|c|c|c|c|c|c|}
\hline \multirow[t]{3}{*}{ VARIABLES } & \multicolumn{2}{|c|}{ DvisitF1 } & \multicolumn{2}{|c|}{ DvisitF2 } & \multicolumn{2}{|c|}{ DvisitF3 } & \multicolumn{2}{|c|}{ DvisitF4 } \\
\hline & (1) & (2) & (3) & (4) & (5) & (6) & (7) & (8) \\
\hline & Busy & Not busy & Busy & Not busy & Busy & Not busy & Busy & Not busy \\
\hline Dvisit & $\begin{array}{c}0.097 * * * \\
(9.30)\end{array}$ & $\begin{array}{c}0.082 * * * \\
(8.73)\end{array}$ & $\begin{array}{c}0.140 * * * \\
(11.23)\end{array}$ & $\begin{array}{c}0.123 * * * \\
(10.91)\end{array}$ & $\begin{array}{c}0.156 * * * \\
(11.21)\end{array}$ & $\begin{array}{c}0.143 * * * \\
(11.05)\end{array}$ & $\begin{array}{c}0.160 * * * \\
(11.10)\end{array}$ & $\begin{array}{c}0.144 * * * \\
(10.28)\end{array}$ \\
\hline Dvisit $\times$ Post & $\begin{array}{c}-0.036 * * * \\
(-2.69)\end{array}$ & $\begin{array}{c}-\mathbf{0 . 0 3 3} * * \\
(-2.45)\end{array}$ & $\begin{array}{c}-0.052 * * * \\
(-3.37)\end{array}$ & $\begin{array}{c}-0.055 * * * \\
(-3.39)\end{array}$ & $\begin{array}{c}-\mathbf{0 . 0 5 5} * * * \\
(-3.16)\end{array}$ & $\begin{array}{c}-0.074 * * * \\
(-4.11)\end{array}$ & $\begin{array}{c}-0.064 * * * \\
(-3.53)\end{array}$ & $\begin{array}{c}-0.077 * * * \\
(-4.10)\end{array}$ \\
\hline Controls & Yes & Yes & Yes & Yes & Yes & Yes & Yes & Yes \\
\hline Firm FE & Yes & Yes & Yes & Yes & Yes & Yes & Yes & Yes \\
\hline Year-week FE & Yes & Yes & Yes & Yes & Yes & Yes & Yes & Yes \\
\hline Observations & 82,286 & 87,210 & 82,286 & 87,210 & 82,286 & 87,210 & 82,286 & 87,210 \\
\hline Adjusted $\mathrm{R}^{2}$ & 0.092 & 0.085 & 0.148 & 0.140 & 0.187 & 0.180 & 0.217 & 0.211 \\
\hline $\begin{array}{l}\text { Difference: } \chi^{2} \\
\text { P-value }\end{array}$ & \multicolumn{2}{|c|}{0.10} & \multicolumn{2}{|c|}{0.01} & $\begin{array}{r}0 . \\
(0 .\end{array}$ & $\begin{array}{l}98 \\
22) \\
\end{array}$ & $\begin{array}{r}0 \\
(0 .\end{array}$ & $\begin{array}{l}38 \\
39) \\
\end{array}$ \\
\hline
\end{tabular}




\section{Table 8 Site Visits by Mutual Funds}

Table 8 reports the results from estimating the equation: Attention $_{i, t}=\alpha+\beta_{1}$ Dvisit $_{i, t}+\beta_{2}$ Post $_{t, t}+\beta_{3}$ Dvisit $_{i, t} \times$ Post $_{t}+\beta_{4}$ Other Controls $+\varepsilon_{i, j, t}$ In Panel A (Panel B), we define a visited firm as one which is visited by at least one analyst or mutual fund (a mutual fund). For a visited firm in week $t$, we measure Attention ${ }_{i, t}$ as an indicator variable that equals one if at least one non-visiting analyst or mutual fund (mutual fund) visits the firm during subsequent weeks. For a non-visited firm $i$, we measure Attention ${ }_{i, t}$ as an indicator variable that equals one if at least one analyst of mutual fund (mutual fund) visits the firm during subsequent weeks. We use $D v i s i t F 1_{i, t}$ (DvisitF2 ${ }_{i, t}$, DvisitF3 $_{i, t}$, DvisitF4 ${ }_{i, t}$ ) to indicate the attention allocated to firm $i$ in the subsequent week (two weeks, three weeks, four weeks). All the variables are defined in the appendix. All the specifications include firm fixed effects and year-week fixed effects. $t$-statistics, based on robust standard errors clustered by firm and year-week are presented below the coefficient estimates.

Panel A Visits by analysts or mutual funds

\begin{tabular}{|c|c|c|c|c|}
\hline VARIABLES & $\begin{array}{c}(1) \\
\text { DvisitF1 }\end{array}$ & $\begin{array}{c}(2) \\
\text { DvisitF2 }\end{array}$ & $\begin{array}{c}(3) \\
\text { DvisitF3 }\end{array}$ & $\begin{array}{c}(4) \\
\text { DvisitF4 }\end{array}$ \\
\hline Dvisit & $\begin{array}{c}0.119 * * * \\
(14.88)\end{array}$ & $\begin{array}{c}0.167 * * * \\
(17.40)\end{array}$ & $\begin{array}{c}0.183^{* * * *} \\
(17.40)\end{array}$ & $\begin{array}{c}0.185^{* * *} * \\
(16.97)\end{array}$ \\
\hline Dvisit $\times$ Post & $\begin{array}{c}-0.049 * * * \\
(-4.69)\end{array}$ & $\begin{array}{c}-0.073 * * * \\
(-5.65)\end{array}$ & $\begin{array}{c}-\mathbf{- 0 . 0 8 0} * * * \\
(-\mathbf{5 . 6 5})\end{array}$ & $\begin{array}{c}-\mathbf{0 . 0 8 4} * * * \\
(-5.75)\end{array}$ \\
\hline$R O A$ & $\begin{array}{c}0.132 * * * \\
(4.28)\end{array}$ & $\begin{array}{c}0.221 * * * \\
(4.45)\end{array}$ & $\begin{array}{c}0.279 * * * \\
(4.42)\end{array}$ & $\begin{array}{c}0.321 * * * \\
(4.34)\end{array}$ \\
\hline Leverage & $\begin{array}{l}-0.006 \\
(-0.44)\end{array}$ & $\begin{array}{l}-0.006 \\
(-0.25)\end{array}$ & $\begin{array}{l}-0.004 \\
(-0.15)\end{array}$ & $\begin{array}{l}-0.005 \\
(-0.14)\end{array}$ \\
\hline Size & $\begin{array}{c}0.011 * * \\
(2.17)\end{array}$ & $\begin{array}{c}0.017 * * \\
(2.15)\end{array}$ & $\begin{array}{c}0.022 * * \\
(2.21)\end{array}$ & $\begin{array}{c}0.028 * * \\
(2.34)\end{array}$ \\
\hline Analyst & $\begin{array}{l}0.003 \\
(1.46)\end{array}$ & $\begin{array}{c}0.008 * * \\
(2.23)\end{array}$ & $\begin{array}{c}0.013 * * * \\
(2.72)\end{array}$ & $\begin{array}{c}0.017 * * * \\
(2.99)\end{array}$ \\
\hline$M B$ & $\begin{array}{c}0.002 * * * \\
(3.38)\end{array}$ & $\begin{array}{c}0.003 * * * \\
(3.30)\end{array}$ & $\begin{array}{c}0.004 * * * \\
(3.22)\end{array}$ & $\begin{array}{c}0.005^{* * *} * \\
(3.23)\end{array}$ \\
\hline$T V$ & $\begin{array}{c}-0.001 * * * \\
(-2.80)\end{array}$ & $\begin{array}{c}-0.002 * * \\
(-2.49)\end{array}$ & $\begin{array}{c}-0.002 * * \\
(-2.17)\end{array}$ & $\begin{array}{c}-0.002^{*} \\
(-1.87)\end{array}$ \\
\hline Return & $\begin{array}{c}0.082 * * * \\
(8.98)\end{array}$ & $\begin{array}{c}0.117 * * * \\
(8.64)\end{array}$ & $\begin{array}{c}0.136 * * * \\
(8.59)\end{array}$ & $\begin{array}{c}0.143 * * * \\
(8.29)\end{array}$ \\
\hline$S T D$ & $\begin{array}{c}0.559 * * * \\
(6.58)\end{array}$ & $\begin{array}{c}0.806^{* * * *} \\
(6.90)\end{array}$ & $\begin{array}{c}0.934 * * * \\
(7.13)\end{array}$ & $\begin{array}{c}0.974 * * * \\
(6.93)\end{array}$ \\
\hline$S O E$ & $\begin{array}{l}-0.012 \\
(-1.23)\end{array}$ & $\begin{array}{l}-0.021 \\
(-1.25)\end{array}$ & $\begin{array}{l}-0.024 \\
(-1.10)\end{array}$ & $\begin{array}{l}-0.028 \\
(-1.08)\end{array}$ \\
\hline Topl & $\begin{array}{l}-0.040 \\
(-0.98)\end{array}$ & $\begin{array}{l}-0.047 \\
(-0.78)\end{array}$ & $\begin{array}{l}-0.043 \\
(-0.58)\end{array}$ & $\begin{array}{l}-0.044 \\
(-0.52)\end{array}$ \\
\hline Constant & $\begin{array}{l}-0.156 \\
(-1.46)\end{array}$ & $\begin{array}{l}-0.246 \\
(-1.42)\end{array}$ & $\begin{array}{l}-0.324 \\
(-1.47)\end{array}$ & $\begin{array}{l}-0.410 \\
(-1.58)\end{array}$ \\
\hline $\begin{array}{l}\text { Firm FE } \\
\text { Year-week FE }\end{array}$ & $\begin{array}{l}\text { Yes } \\
\text { Yes }\end{array}$ & $\begin{array}{l}\text { Yes } \\
\text { Yes }\end{array}$ & $\begin{array}{l}\text { Yes } \\
\text { Yes }\end{array}$ & $\begin{array}{l}\text { Yes } \\
\text { Yes }\end{array}$ \\
\hline $\begin{array}{l}\text { Observations } \\
\text { Adjusted } \mathrm{R}^{2} \\
\end{array}$ & $\begin{array}{c}169,450 \\
0.108 \\
\end{array}$ & $\begin{array}{c}169,450 \\
0.169 \\
\end{array}$ & $\begin{array}{c}169,450 \\
0.209\end{array}$ & $\begin{array}{c}169,450 \\
0.239\end{array}$ \\
\hline
\end{tabular}


Panel B Visits by mutual funds

\begin{tabular}{|c|c|c|c|c|}
\hline VARIABLES & $\begin{array}{c}\text { (1) } \\
\text { DvisitF1 }\end{array}$ & $\begin{array}{c}(2) \\
\text { DvisitF2 }\end{array}$ & $\begin{array}{c}\text { (3) } \\
\text { DvisitF3 }\end{array}$ & $\begin{array}{c}(4) \\
\text { DvisitF4 }\end{array}$ \\
\hline Dvisit & $\begin{array}{c}0.080 * * * \\
(10.69)\end{array}$ & $\begin{array}{c}0.118 * * * \\
(11.93)\end{array}$ & $\begin{array}{c}0.136 * * * \\
(12.69)\end{array}$ & $\begin{array}{c}0.150 * * * \\
(13.27)\end{array}$ \\
\hline Dvisit $\times$ Post & $\begin{array}{c}-0.032 * * * \\
(-3.18)\end{array}$ & $\begin{array}{c}-0.060 * * * \\
(-4.72)\end{array}$ & $\begin{array}{c}-0.069 * * * \\
(-4.90)\end{array}$ & $\begin{array}{c}-0.090 * * * \\
(-6.01)\end{array}$ \\
\hline$R O A$ & $\begin{array}{c}0.089 * * * \\
(4.09)\end{array}$ & $\begin{array}{c}0.152 * * * \\
(3.94)\end{array}$ & $\begin{array}{l}0.208 * * * \\
(4.10)\end{array}$ & $\begin{array}{c}0.256 * * * \\
(4.18)\end{array}$ \\
\hline Leverage & $\begin{array}{l}-0.003 \\
(-0.30)\end{array}$ & $\begin{array}{l}-0.003 \\
(-0.21)\end{array}$ & $\begin{array}{l}-0.003 \\
(-0.13)\end{array}$ & $\begin{array}{l}-0.001 \\
(-0.04)\end{array}$ \\
\hline Size & $\begin{array}{c}0.007 * * \\
(2.25)\end{array}$ & $\begin{array}{c}0.011 * * \\
(2.14)\end{array}$ & $\begin{array}{c}0.014 * * \\
(1.98)\end{array}$ & $\begin{array}{l}0.017 * \\
(1.95)\end{array}$ \\
\hline Analyst & $\begin{array}{l}0.002 \\
(1.50)\end{array}$ & $\begin{array}{l}0.004 \\
(1.65)\end{array}$ & $\begin{array}{l}0.007 * \\
(1.84)\end{array}$ & $\begin{array}{l}0.009^{*} \\
(1.96)\end{array}$ \\
\hline$M B$ & $\begin{array}{c}0.002 * * * \\
(4.05)\end{array}$ & $\begin{array}{c}0.003 * * * \\
(4.04)\end{array}$ & $\begin{array}{c}0.004 * * * \\
(3.98)\end{array}$ & $\begin{array}{c}0.005 * * * \\
(4.02)\end{array}$ \\
\hline$T V$ & $\begin{array}{c}-0.001 * * * \\
(-2.98)\end{array}$ & $\begin{array}{c}-0.002 * * * \\
(-2.80)\end{array}$ & $\begin{array}{c}-0.002 * * * \\
(-2.70)\end{array}$ & $\begin{array}{c}-0.003 * * * \\
(-2.68)\end{array}$ \\
\hline Return & $\begin{array}{c}0.067 * * * \\
(9.06)\end{array}$ & $\begin{array}{c}0.103 * * * \\
(8.69)\end{array}$ & $\begin{array}{c}0.126 * * * \\
(8.75)\end{array}$ & $\begin{array}{c}0.134 * * * \\
(8.43)\end{array}$ \\
\hline$S T D$ & $\begin{array}{c}0.440 * * * \\
(6.70)\end{array}$ & $\begin{array}{c}0.631 * * * \\
(6.55)\end{array}$ & $\begin{array}{c}0.782 * * * \\
(7.13)\end{array}$ & $\begin{array}{c}0.844 * * * \\
(7.05)\end{array}$ \\
\hline$S O E$ & $\begin{array}{c}-0.012 * \\
(-1.78)\end{array}$ & $\begin{array}{l}-0.021 * \\
(-1.73)\end{array}$ & $\begin{array}{c}-0.029 * \\
(-1.82)\end{array}$ & $\begin{array}{c}-0.035^{*} \\
(-1.83)\end{array}$ \\
\hline Topl & $\begin{array}{l}-0.026 \\
(-1.14)\end{array}$ & $\begin{array}{l}-0.038 \\
(-0.98)\end{array}$ & $\begin{array}{l}-0.042 \\
(-0.82)\end{array}$ & $\begin{array}{l}-0.050 \\
(-0.79)\end{array}$ \\
\hline Constant & $\begin{array}{l}-0.103 \\
(-1.63)\end{array}$ & $\begin{array}{l}-0.170 \\
(-1.48)\end{array}$ & $\begin{array}{l}-0.203 \\
(-1.31)\end{array}$ & $\begin{array}{l}-0.241 \\
(-1.26)\end{array}$ \\
\hline $\begin{array}{l}\text { Firm FE } \\
\text { Year-week FE }\end{array}$ & $\begin{array}{l}\text { Yes } \\
\text { Yes }\end{array}$ & $\begin{array}{l}\text { Yes } \\
\text { Yes }\end{array}$ & $\begin{array}{l}\text { Yes } \\
\text { Yes }\end{array}$ & $\begin{array}{l}\text { Yes } \\
\text { Yes }\end{array}$ \\
\hline $\begin{array}{l}\text { Observations } \\
\text { Adjusted } \mathrm{R}^{2}\end{array}$ & $\begin{array}{c}169,589 \\
0.067\end{array}$ & $\begin{array}{c}169,589 \\
0.114\end{array}$ & $\begin{array}{c}169,589 \\
0.150\end{array}$ & $\begin{array}{c}169,589 \\
0.179\end{array}$ \\
\hline
\end{tabular}




\section{Table 9 Alternative Measures of Analysts' Attention}

In Table 9, we use the tendency to issue forecast revisions as an alternative measure of analysts' attention. All the variables are defined in the appendix. All the specifications include firm fixed effects and year fixed effects. $t$-statistics, based on robust standard errors clustered by firm and year-week are presented below the coefficient estimates.

\begin{tabular}{|c|c|c|c|c|}
\hline VARIABLES & $\begin{array}{c}(1) \\
\text { DRevision } 1\end{array}$ & $\begin{array}{c}(2) \\
\text { DRevision2 }\end{array}$ & $\begin{array}{c}\text { (3) } \\
\text { DRevision3 }\end{array}$ & $\begin{array}{c}\text { (4) } \\
\text { DRevision4 }\end{array}$ \\
\hline Dvisit & $\begin{array}{l}0.001 \\
(0.22)\end{array}$ & $\begin{array}{l}-0.006 \\
(-0.87)\end{array}$ & $\begin{array}{l}-0.002 \\
(-0.28)\end{array}$ & $\begin{array}{l}0.003 \\
(0.29)\end{array}$ \\
\hline Dvisit $\times$ Post & $\begin{array}{c}-0.023 * * * \\
(-3.13)\end{array}$ & $\begin{array}{c}-0.027 * * * \\
(-2.74)\end{array}$ & $\begin{array}{c}-0.036 * * * \\
(-3.17)\end{array}$ & $\begin{array}{c}-0.039 * * * \\
(-3.11)\end{array}$ \\
\hline$R O A$ & $\begin{array}{c}0.182 * * * \\
(6.02)\end{array}$ & $\begin{array}{c}0.322 * * * \\
(6.45)\end{array}$ & $\begin{array}{c}0.429 * * * \\
(6.60)\end{array}$ & $\begin{array}{c}0.495^{* * *} \\
(6.54)\end{array}$ \\
\hline Leverage & $\begin{array}{l}0.022 \\
(1.50)\end{array}$ & $\begin{array}{l}0.036 \\
(1.50)\end{array}$ & $\begin{array}{l}0.047 \\
(1.48)\end{array}$ & $\begin{array}{l}0.048 \\
(1.30)\end{array}$ \\
\hline Size & $\begin{array}{c}0.023 * * * \\
(5.26)\end{array}$ & $\begin{array}{c}0.038 * * * \\
(5.44)\end{array}$ & $\begin{array}{c}0.049 * * * \\
(5.48)\end{array}$ & $\begin{array}{c}0.057 * * * \\
(5.55)\end{array}$ \\
\hline Analyst & $\begin{array}{c}0.019 * * * \\
(7.71)\end{array}$ & $\begin{array}{c}0.032 * * * \\
(8.09)\end{array}$ & $\begin{array}{c}0.043 * * * \\
(8.36)\end{array}$ & $\begin{array}{c}0.052 * * * \\
(8.59)\end{array}$ \\
\hline$M B$ & $\begin{array}{c}0.003 * * * \\
(5.05)\end{array}$ & $\begin{array}{c}0.006 * * * \\
(5.19)\end{array}$ & $\begin{array}{c}0.007 * * * \\
(5.24)\end{array}$ & $\begin{array}{c}0.009 * * * \\
(5.32)\end{array}$ \\
\hline$T V$ & $\begin{array}{l}-0.001 \\
(-1.11)\end{array}$ & $\begin{array}{l}-0.001 \\
(-1.25)\end{array}$ & $\begin{array}{l}-0.001 \\
(-1.32)\end{array}$ & $\begin{array}{l}-0.001 \\
(-1.09)\end{array}$ \\
\hline Return & $\begin{array}{c}0.100 * * * \\
(9.85)\end{array}$ & $\begin{array}{c}0.146 * * * \\
(10.06)\end{array}$ & $\begin{array}{c}0.163 * * * \\
(10.00)\end{array}$ & $\begin{array}{c}0.170 * * * \\
(9.68)\end{array}$ \\
\hline$S T D$ & $\begin{array}{c}0.565 * * * \\
(5.05)\end{array}$ & $\begin{array}{c}0.810 * * * \\
(5.29)\end{array}$ & $\begin{array}{c}0.990 * * * \\
(5.66)\end{array}$ & $\begin{array}{c}1.006^{* * * *} \\
(5.56)\end{array}$ \\
\hline$S O E$ & $\begin{array}{l}-0.007 \\
(-0.74)\end{array}$ & $\begin{array}{l}-0.015 \\
(-0.91)\end{array}$ & $\begin{array}{l}-0.023 \\
(-1.06)\end{array}$ & $\begin{array}{l}-0.029 \\
(-1.20)\end{array}$ \\
\hline Topl & $\begin{array}{l}-0.022 \\
(-0.91)\end{array}$ & $\begin{array}{l}-0.045 \\
(-1.17)\end{array}$ & $\begin{array}{l}-0.063 \\
(-1.28)\end{array}$ & $\begin{array}{l}-0.075 \\
(-1.29)\end{array}$ \\
\hline Constant & $\begin{array}{c}-0.469 * * * \\
(-4.98)\end{array}$ & $\begin{array}{c}-0.747 * * * \\
(-5.02)\end{array}$ & $\begin{array}{c}-0.941 * * * \\
(-5.00)\end{array}$ & $\begin{array}{c}-1.085 * * * \\
(-4.98)\end{array}$ \\
\hline Firm FE & Yes & Yes & Yes & Yes \\
\hline Year-week FE & Yes & Yes & Yes & Yes \\
\hline $\begin{array}{l}\text { Observations } \\
\text { Adjusted } \mathrm{R}^{2}\end{array}$ & $\begin{array}{c}169,496 \\
0.130\end{array}$ & $\begin{array}{c}169,496 \\
0.208\end{array}$ & $\begin{array}{c}169,496 \\
0.266\end{array}$ & $\begin{array}{c}169,496 \\
0.311\end{array}$ \\
\hline
\end{tabular}




\section{Table 10 Firm-week-analyst Level Tests}

We re-estimate equation (1) based on firm-week-analyst level and present the results in Table 10. All the variables are defined in Appendix 2. All the specifications include firm fixed effects and year fixed effects. $t$-statistics, based on robust standard errors clustered by firm and year-week, are presented below the coefficient estimates.

\begin{tabular}{|c|c|c|c|c|}
\hline VARIABLES & $\begin{array}{c}(1) \\
\text { DvisitF1 }\end{array}$ & $\begin{array}{c}(2) \\
\text { DvisitF2 }\end{array}$ & $\begin{array}{c}(3) \\
\text { DvisitF3 }\end{array}$ & $\begin{array}{c}(4) \\
\text { DvisitF4 }\end{array}$ \\
\hline$\overline{D v i s i t}$ & $\begin{array}{c}0.007 * * * \\
(6.00)\end{array}$ & $\begin{array}{c}0.011 * * * \\
(5.70)\end{array}$ & $\begin{array}{c}0.013 * * * \\
(5.17)\end{array}$ & $\begin{array}{c}0.015^{* * * *} \\
(4.81)\end{array}$ \\
\hline Dvisit $\times$ Post & $\begin{array}{c}-0.004 * * \\
(-2.03)\end{array}$ & $\begin{array}{c}-0.007 * * \\
(-2.51)\end{array}$ & $\begin{array}{c}-0.011 * * * \\
(-2.89)\end{array}$ & $\begin{array}{c}-0.011 * * * \\
(-2.76)\end{array}$ \\
\hline Brokersize & $\begin{array}{c}0.000 * * * \\
(7.23)\end{array}$ & $\begin{array}{c}0.000 * * * \\
(7.40)\end{array}$ & $\begin{array}{c}0.000 * * * \\
(7.51)\end{array}$ & $\begin{array}{c}0.000 * * * \\
(7.58)\end{array}$ \\
\hline Firmexperience & $\begin{array}{c}0.001^{*} \\
(1.82)\end{array}$ & $\begin{array}{c}0.003 * * \\
(2.02)\end{array}$ & $\begin{array}{c}0.004 * * \\
(1.98)\end{array}$ & $\begin{array}{c}0.004 * \\
(1.83)\end{array}$ \\
\hline Companies & $\begin{array}{c}0.001 * * \\
(2.48)\end{array}$ & $\begin{array}{c}0.001 * * \\
(2.27)\end{array}$ & $\begin{array}{c}0.002 * * \\
(2.33)\end{array}$ & $\begin{array}{c}0.002 * * \\
(2.25)\end{array}$ \\
\hline Star & $\begin{array}{c}0.004 * * * \\
(8.30)\end{array}$ & $\begin{array}{c}0.008^{* * * *} \\
(8.22)\end{array}$ & $\begin{array}{c}0.012 * * * \\
(8.41)\end{array}$ & $\begin{array}{c}0.016^{* * *} \\
(8.47)\end{array}$ \\
\hline$R O A$ & $\begin{array}{l}0.002 \\
(0.12)\end{array}$ & $\begin{array}{l}0.004 \\
(0.15)\end{array}$ & $\begin{array}{l}0.000 \\
(0.01)\end{array}$ & $\begin{array}{l}-0.000 \\
(-0.00)\end{array}$ \\
\hline Leverage & $\begin{array}{l}-0.001 \\
(-0.22)\end{array}$ & $\begin{array}{l}-0.002 \\
(-0.24)\end{array}$ & $\begin{array}{l}-0.004 \\
(-0.37)\end{array}$ & $\begin{array}{l}-0.006 \\
(-0.40)\end{array}$ \\
\hline Size & $\begin{array}{l}0.001 \\
(0.78)\end{array}$ & $\begin{array}{l}0.003 \\
(0.78)\end{array}$ & $\begin{array}{l}0.005 \\
(0.97)\end{array}$ & $\begin{array}{l}0.006 \\
(0.89)\end{array}$ \\
\hline Analyst & $\begin{array}{l}0.001 \\
(1.37)\end{array}$ & $\begin{array}{l}0.003 \\
(1.52)\end{array}$ & $\begin{array}{l}0.003 \\
(1.40)\end{array}$ & $\begin{array}{l}0.004 \\
(1.29)\end{array}$ \\
\hline$M B$ & $\begin{array}{l}-0.000 \\
(-0.06)\end{array}$ & $\begin{array}{l}-0.000 \\
(-0.02)\end{array}$ & $\begin{array}{l}0.000 \\
(0.24)\end{array}$ & $\begin{array}{l}0.000 \\
(0.30)\end{array}$ \\
\hline$T V$ & $\begin{array}{l}-0.000 \\
(-0.30)\end{array}$ & $\begin{array}{l}-0.000 \\
(-0.16)\end{array}$ & $\begin{array}{l}-0.000 \\
(-0.17)\end{array}$ & $\begin{array}{l}-0.000 \\
(-0.34)\end{array}$ \\
\hline Return & $\begin{array}{c}0.010 * * * \\
(2.80)\end{array}$ & $\begin{array}{c}0.017 * * * \\
(2.79)\end{array}$ & $\begin{array}{c}0.025 * * * \\
(2.83)\end{array}$ & $\begin{array}{c}0.028 * * \\
(2.45)\end{array}$ \\
\hline$S T D$ & $\begin{array}{c}0.125^{* * *} * \\
(3.59)\end{array}$ & $\begin{array}{c}0.189 * * * \\
(3.81)\end{array}$ & $\begin{array}{c}0.207 * * * \\
(3.09)\end{array}$ & $\begin{array}{c}0.270^{* * * *} \\
(3.45)\end{array}$ \\
\hline$S O E$ & $\begin{array}{l}0.001 \\
(0.23)\end{array}$ & $\begin{array}{l}0.001 \\
(0.15)\end{array}$ & $\begin{array}{l}0.002 \\
(0.20)\end{array}$ & $\begin{array}{l}0.002 \\
(0.16)\end{array}$ \\
\hline Topl & $\begin{array}{c}-0.016^{*} \\
(-1.84)\end{array}$ & $\begin{array}{l}-0.030 \\
(-1.64)\end{array}$ & $\begin{array}{l}-0.042 \\
(-1.53)\end{array}$ & $\begin{array}{l}-0.056 \\
(-1.53)\end{array}$ \\
\hline Constant & $\begin{array}{l}-0.030 \\
(-0.76)\end{array}$ & $\begin{array}{l}-0.057 \\
(-0.75)\end{array}$ & $\begin{array}{l}-0.102 \\
(-0.92)\end{array}$ & $\begin{array}{l}-0.121 \\
(-0.82)\end{array}$ \\
\hline $\begin{array}{l}\text { Firm FE } \\
\text { Year-week FE }\end{array}$ & $\begin{array}{l}\text { Yes } \\
\text { Yes }\end{array}$ & $\begin{array}{l}\text { Yes } \\
\text { Yes }\end{array}$ & $\begin{array}{l}\text { Yes } \\
\text { Yes }\end{array}$ & $\begin{array}{l}\text { Yes } \\
\text { Yes }\end{array}$ \\
\hline $\begin{array}{l}\text { Observations } \\
\text { Adjusted } \mathrm{R}^{2}\end{array}$ & $\begin{array}{c}318,128 \\
0.009\end{array}$ & $\begin{array}{c}318,128 \\
0.018\end{array}$ & $\begin{array}{c}318,128 \\
0.025\end{array}$ & $\begin{array}{c}318,128 \\
0.032\end{array}$ \\
\hline
\end{tabular}

